CEPAL REVIEW 89 • AUGUST 2006

\title{
Gaps in the welfare State and reforms to pension systems in Latin America
}

\author{
Andras Uthoff
}

$\mathrm{P}$

ension systems in Latin America are organized as tripartite contributory schemes paid into by employers, employees and the State. Their coverage has always been segmented and very low because a significant percentage of the labour market is composed of subsistence sectors with low productivity and unstable, uncertain access to commercial and financial networks (associated with a lack of employment protections, low income levels and a high incidence of poverty). As a result, contributory systems exclude a large proportion of workers and their families from protection against the risks of disability, old age and death, with large differences in coverage between the formal and informal sectors. The main challenge now is to incorporate solidarity financing into pension systems in an efficient way, so that contributory and noncontributory schemes can be combined in accordance with the logic of social security. 


\section{I}

\section{Introduction}

Pension systems have been designed with a view to smoothing fluctuations in consumption over the life cycle and ensuring decent incomes in situations of old age, disability and death. Their functions are social in nature, as they aim to remedy short-sighted decisionmaking about saving for old age and to use solidarity financing to provide the elderly poor with income. Nowadays, emphasis is also placed on their potential economic functions, such as contributing to the solvency of the public finances, providing financial savings for capital market development and making labour more competitive by reducing employment costs.

The development of these systems has been based on two assumptions: (i) workers are fully employed and in a position to save throughout their active life cycle, and (ii) families have one main provider whose insurance protects the other members. With these premises, systems combine contributory instruments (saving and insurance) to finance benefits in the event of unforeseen losses of income resulting from disablement and premature death, and to ensure a decent old age (life expectancy). Contributions have traditionally been tripartite, being made by workers, employers and the State, and their purpose has been to protect the workers themselves, in their capacity as main earners, and their families. In some countries there are non-contributory pensions for poor older adults, and these are financed out of general taxation.

This article places the debate about pension system reforms in the context of the region's main characteristics, then goes on to examine the implications these characteristics have for the assumptions by which pension systems work. In the light of these considerations, it analyses the validity of the reform options chosen, highlights the main results observed in the region and formulates some conclusions about the importance of the role to be played in solving the pensions issue by the ECLAC proposal for the development of a social cohesion covenant to give the fiscal covenant a human face.

\section{II}

\section{The main characteristics of the region}

The extent to which the structural characteristics of the Latin American and Caribbean countries have been overlooked is striking, since knowledge of these has proved essential for evaluating pension system performance, almost irrespective of the type of reform carried out. Here I would like to highlight just five of these characteristics. First, the region's average development level: its per capita gross domestic product (GDP) averages a little over US $\$ 5,000$, which places it well above developing regions in Africa and Asia, but is only a fifth of the average for the group of developed countries in the Organisation for Economic Co-operation and Development (OECD) (figure 1). The main effect of this characteristic is that, in the new globalization paradigm, Latin America and the Caribbean have been treated as a middle-income region capable of attracting international capital to meet its development needs and of entering into free trade agreements to sell its products on international markets. Actually, though, far from consolidating stable access to these markets, international capital flows have been elusive for some countries and volatile for others, and trade continues to be constrained by protectionism and unstable commodity prices. The fact is that the region's countries have seen their external vulnerability increase, have experienced severe trade and financing crises, and have had to weather major financial and balance-of-payments crises, with enormous social costs in the adjustment phases.

Second, the region has a history of inequality. Measured by the Gini coefficient, in fact, it is the world's most unequal. What this chiefly means is that, at current development levels, large sections of the population have been left in poverty and indigence and that, with inequality patterns like these, higher growth rates are required to defeat poverty (ECLAC, 
FIGURE 1

Major regions: Gross domestic product per capita and Gini coefficients

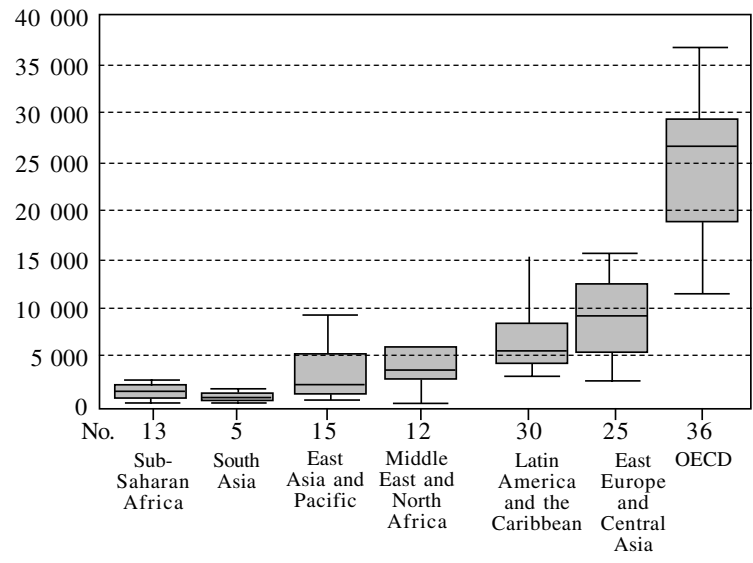

Source: Prepared by the author from World Bank (2004) data.

2005a)-and these higher rates have not been forthcoming in the region in any stable fashion for decades.

Third, some indicators produced by ECLAC suggest that the region's economies have largely implemented the recommendations of international financial institutions concerning the introduction of structural reforms to liberalize the economy and give a larger role to the market and the private sector in the allocation of resources (figure 2). This has exposed major shortcomings in market regulation and oversight in the new industries that have grown up around public services and social policy management.

Fourth, it is important to note that while the proposed reforms to limit the role of the State to that of regulator, supervisor and distributor prevent it from managing enterprises, ${ }^{1}$ they do not release it from its responsibility for designing and implementing mechanisms to protect the rights of the poorest, especially against health risks and employment and pension problems. In particular, it has to protect them against the structural risk represented by the mechanisms that transfer poverty across the generations, i.e., against exclusion from opportunities (in terms of nutrition, food, housing and decent work), which is largely a result of the poverty into which many of its citizens are born.

\footnotetext{
${ }^{1}$ Although many countries have kept the management of strategic enterprises in the public sector (for example, copper companies in Chile and oil companies in Mexico and the Bolivarian Republic of Venezuela).
}

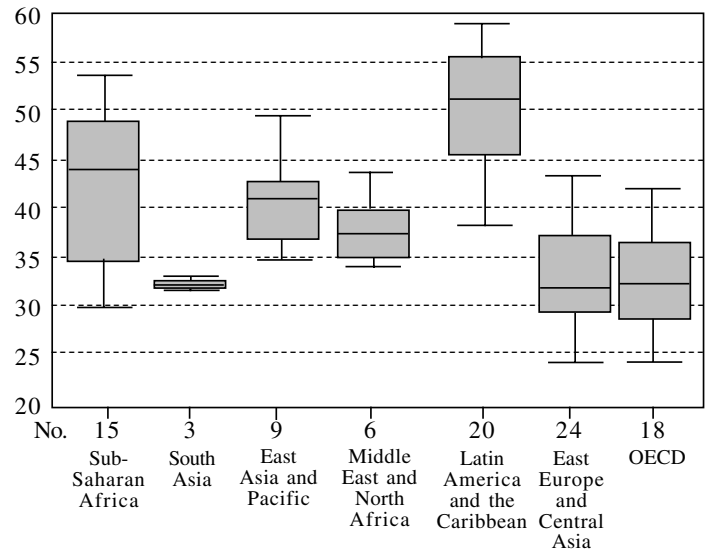

With the development issues that concern us, a paradox arises: the less developed a country is, the greater the needs are, but the lower the tax take from which governments can finance this goal. As figure 3 shows, public spending in Latin America as a percentage of GDP rose from $15 \%$ to $25 \%$ between the 1970 s and 1980s, but then fell back to around $20 \%$. This is less than half the equivalent figure in the countries of the European Union, where the welfare State is sizeable. Since the level of development in the European Union as expressed in per capita GDP is five times that of Latin America, it follows that public spending per person in the European Union is ten times Latin America's.

Lastly, we cannot ignore the risks entailed by globalization, which create a new dilemma for social protection systems. Because Latin America has come to be seen as a middle-income region, the countries have had to look to international markets for development financing sources and outlets for their export products. Thus, these economies have become more vulnerable to changes in international markets, and this, in the absence of an international financial architecture to coordinate macroeconomies and ensure stability, has made them far more sensitive to international crises. From the point of view of social protection, it is important to recognize that the regional economy has become more volatile and uncertain and that the adjustment measures applied to cope with financial crises entailing major social costs have been procyclical and placed extra pressure on the labour market, increasing problems of underemployment and 
FIGURE 2

Latin America (17 countries): Convergence of reforms over time

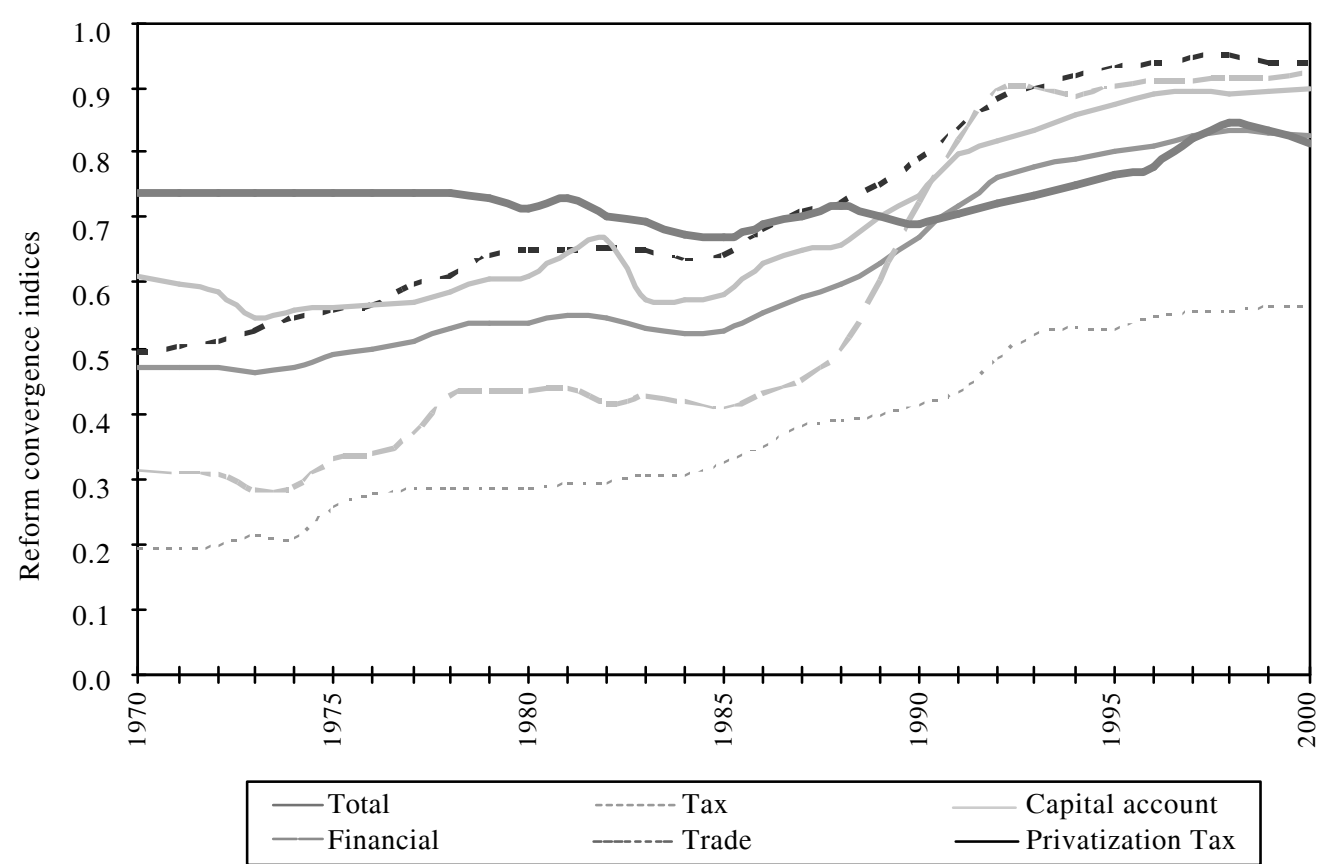

Source: ECLAC, on the basis of the project "Growth, employment and equity: Latin America and the Caribbean in the 1990s" (HOL/97/6034), with data to 1995 from Morley, Machado and Pettinato (1999).

FIGURE 3

\section{International comparisons: Public spending, 1970-2005}

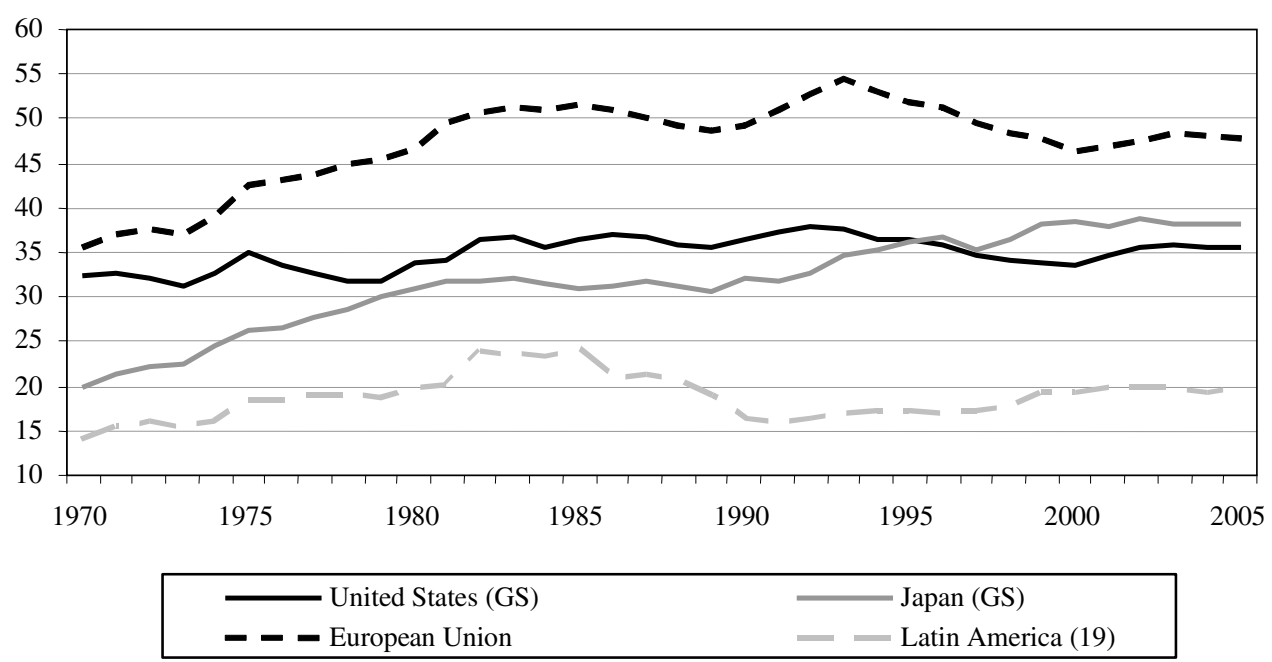

Source: For Latin America, ECLAC data based on official information; for European Union countries, Japan and the United States, data from the Organisation for Economic Co-operation and Development (OECD).

${ }^{\mathrm{a}} \mathrm{GS}=$ government spending. 
unemployment and forcing the State to cut spending just when the need for it is greatest.

In summary, social protection in Latin America needs to improve in the context of societies that, on the one hand, are considered "mature" and that, within the paradigm of globalization, are having to pursue their development in an ever more unstable world and subject their economies to increasing liberalization, reducing the role of the State. Yet, on the other hand, these societies have a history of inequality between their citizens, and of low growth and investment crises as well, so that their governments lack the instruments needed to solve long-standing problems of inequality in the midst of growth and employment crises.

\section{III}

\section{The consequences for social protection}

The characteristics of the region have at least four implications for the development of new social protection systems. These are: (i) the gap that opens up in the welfare State when the dynamics of the population, the labour market and the public finances are combined; (ii) the new cultural phenomena deriving from the survival strategies that families have had to adopt to cope with this situation; (iii) the region's growing divergence from the most developed countries in recent decades; and (iv) lastly, the belief that the fight against poverty is not succeeding as intended.

Although the region as a whole is in a phase of full demographic transition, the population dynamic varies between different groups of countries. Thus, a group consisting of Bolivia and Haiti is at an incipient stage, with fertility rates that are still high and a growing youth population as compared to that of working age. A second group, composed of El Salvador, Guatemala, Honduras, Nicaragua and Paraguay, is in a moderate phase of the demographic transition; there has been a sharp drop in fertility and the young population is starting to decline in relation to the working-age population, but the proportion of elderly people is still low. A third group of countries, consisting of Brazil, Ecuador, Colombia, Costa Rica, Mexico, Peru, the Bolivarian Republic of Venezuela and the Dominican Republic, is in full demographic transition; lower fertility was consolidated some years ago, and not only is the young population still decreasing in relation to the working-age population, but the elderly population is beginning to rise as well. Lastly, a fourth group of countries is at an advanced stage of the demographic transition, has consolidated the drop in fertility, continues to show substantial progress in reducing mortality and is seeing a significant increase in the proportion of elderly people in relation to those of working age.
Although this indicator is traditionally used to measure demographic dependency and anticipate possible shortfalls in the solvency of unfunded pension financing systems, it involves an assumption that the working-age population is able and willing to find productive, competitive and/or decent work. However, the data for Latin America reveal three facts which show that this is far from being the case. First, a large percentage of people of working age remain inactive, either because it is difficult to participate in the labour market while also looking after the home or because the market does not adequately price in their opportunity costs. Second, of those who are willing to work, the proportion failing to find jobs and remaining unemployed has risen from $7 \%$ to $10 \%$, so that one in ten is now jobless. Lastly, estimates by the International Labour Organization (ILO) and ECLAC indicate that six to seven of every ten new jobs in recent years have been created in the informal sector, so that the proportion of working people employed in this segment of the labour market has increased (figures 4 and 5).

\section{The gap in the welfare State}

To characterize the gap in the welfare State, it is essential to have an understanding of changes in the demographic dynamic, the labour market and public finances.

In an earlier article (Uthoff, Vera and Ruedi, 2006), national panel data ${ }^{2}$ for 1997 and 2002 were used to examine the behaviour of a dependency indicator defined as the ratio of minors, non-active adults, adults

\footnotetext{
${ }^{2}$ Urban data were used for Argentina and Uruguay, as this was what was available, but the bulk of those countries' population is urban in any case. Details of how the curve was derived can be found in Uthoff, Vera and Ruedi (2006).
} 
FIGURE 4

Latin America: Open unemployment, ages $\mathbf{1 5}$ to $\mathbf{6 4}$

(Percentages of the economically active population)

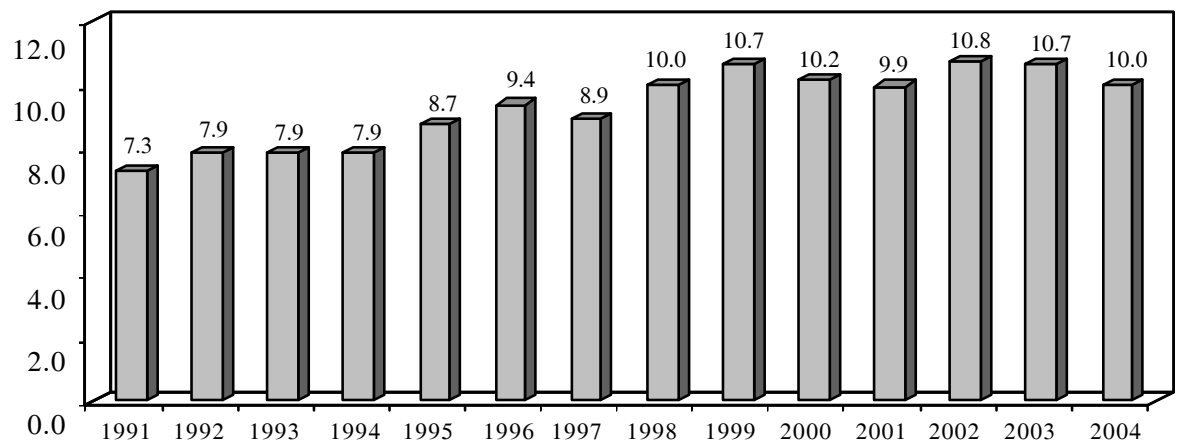

Source: International Labour Organization (ECLAC, 2005b).

FIGURE 5

Latin America: Structure of non-agricultural employment

(Percentages)

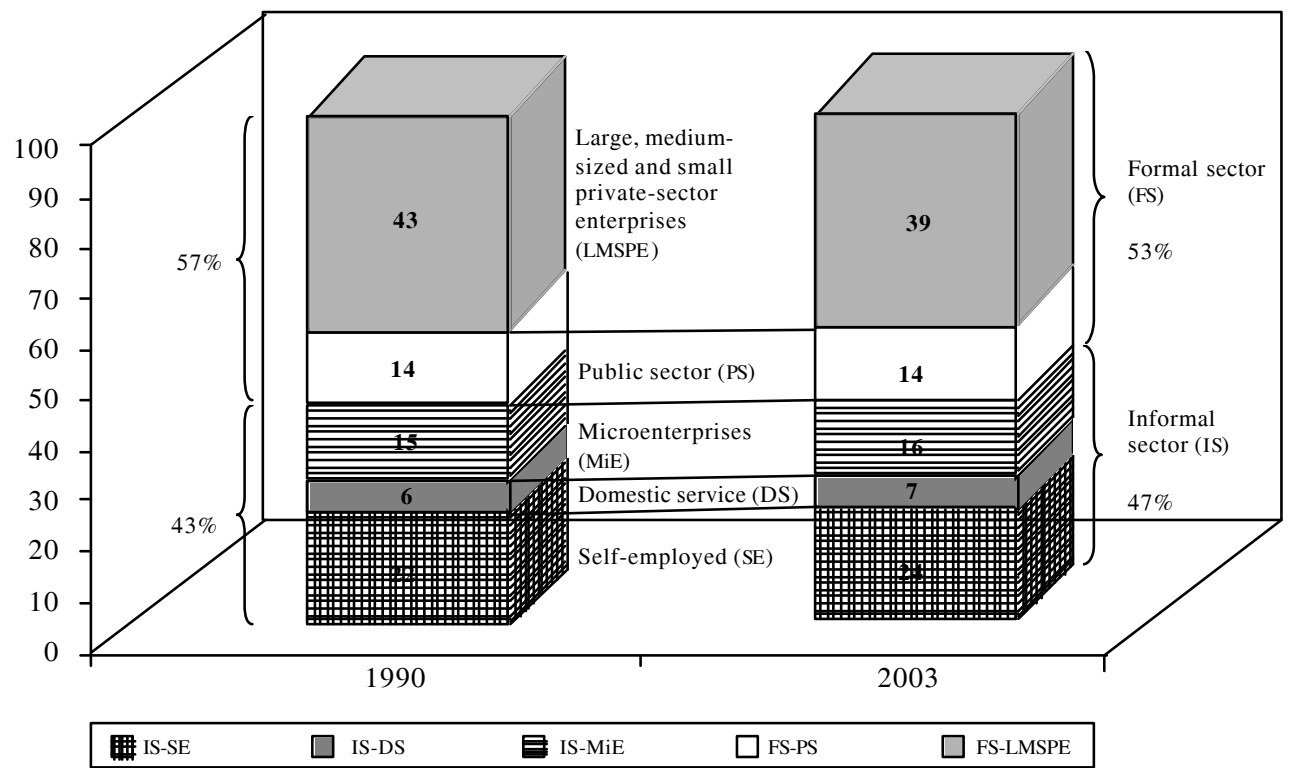

Source: International Labour Organization (ILO, 2005).

with informal jobs, unemployed people and older adults to formal workers. The regression yielded a negative coefficient of $-2.65 \%$ for the ratio between the formal dependency indicator and per capita GDP. ${ }^{3}$ This ratio

\footnotetext{
${ }^{3}$ The estimation of the regression on the basis of panel data can be obtained on request from the authors cited, as can the Hausman test on the applicability of the random effects model. The same coefficient would be yielded by an estimation using pooled data. The 2002 per capita GDP data are taken from the World Bank's World Development Indicators and are expressed in 2000 prices.
}

systematically represents the demand for social protection.

Countries with high dependency indices and low per capita incomes have a high demand for social protection, which has to be met from public or private transfers. Lesser requirements are faced by richer countries.

A potential supply curve for State-provided social services can be derived by linking the countries' per capita GDP to the number of dependent people in relation to the number of people in formal work that could be "protected" by them. For this, we assume that 
the State is capable of providing each dependent with a given amount of benefits (the same for all categories of dependents) whose sum equals the total amount of resources spent on social services in Latin America. ${ }^{4}$

By including both curves in figure 3 , it is possible to illustrate the gap in the welfare State and thereby create a typology of countries. ${ }^{5}$

While the existence of a welfare gap justifies system models that seek supplementary private financing, it does not remove the State's responsibility for protecting those who reach old age without having been able to finance their own pension benefits. The main weakness of the recent reforms has been their over-reliance on contributory systems, their high cost, and their effect in depriving the State of resources for alleviating old-age poverty.

\section{Two new cultural phenomena}

The higher the overall level of development as measured by per capita GDP (figure 6), the smaller the gap between the overall social protection needs of dependents and the ability of the State to meet them. These social protection needs can be covered by the rest of the economy to a degree that depends on the income situation and people's capacity for out-ofpocket expenditure. In cases where public-sector social protection combined with private spending is inadequate, the resulting gap will be manifested in poor social indicators; by bringing about an unsatisfactory social situation, this shortfall has led to major changes in family structures (Arriagada, 2005) and in substantial remittance movements resulting from migration, which are estimated to have helped mitigate poverty in thousands of households in the region (figures 7 and 8).

\section{Latin America is not converging}

The third characteristic of the region is that the last decade has not been one of high, stable growth. On the contrary, as ECLAC reported to the International Conference on Financing for Development, opening the region up to international trade and financial markets increased its external vulnerability and resulted

FIGURE 6

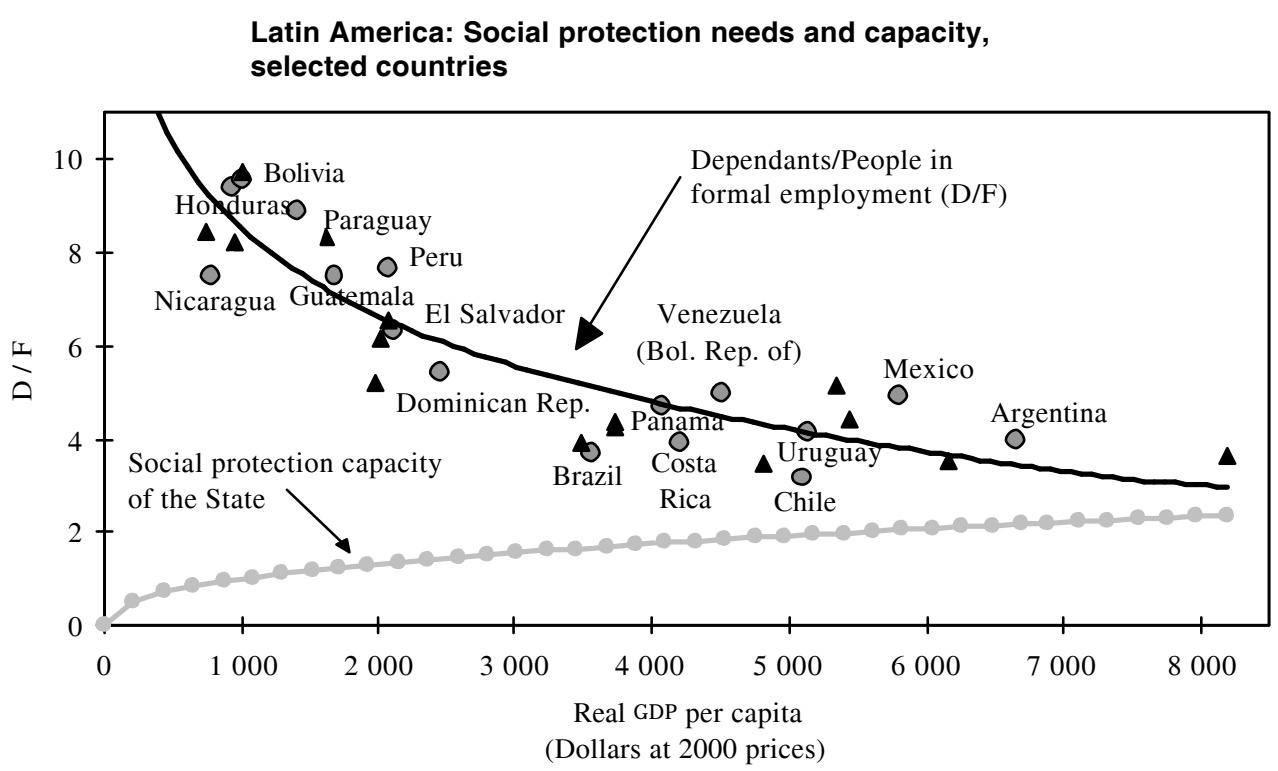

○ $2002 \boldsymbol{\Delta} 1997$

Source: Prepared by the author.

\footnotetext{
${ }^{4}$ Average social spending in Latin America was calculated from a sample of 16 countries.
}

${ }^{5}$ The $\beta$ used in this case is 0.35 . 
in unstable and, on average, low growth. In particular, access to international financial markets was segmented and highly volatile, export markets continued with protectionist practices, and growth ultimately proved sensitive to international financial crises. The international financial architecture, meanwhile, was unable to prevent contagion in the region.

The outcome is reflected in the trend of per capita GDP. With very few exceptions, per capita GDP in the region's countries was higher as a share of United States GDP in 1993 than in 2003, as the new millennium began. Going by this very preliminary indicator of development, the region did not converge towards United States levels of development (figure 9).

What makes the situation even worse is that, what with the high levels of inequality within Latin America, low growth, the effect of debt crises and the incidence of poverty ( $40 \%$ of the population), it can be concluded that the region's inhabitants are still living in much the same way as those of heavily indebted poor countries, such as Nicaragua. In short, the region has a high level of exclusion (figure 10).

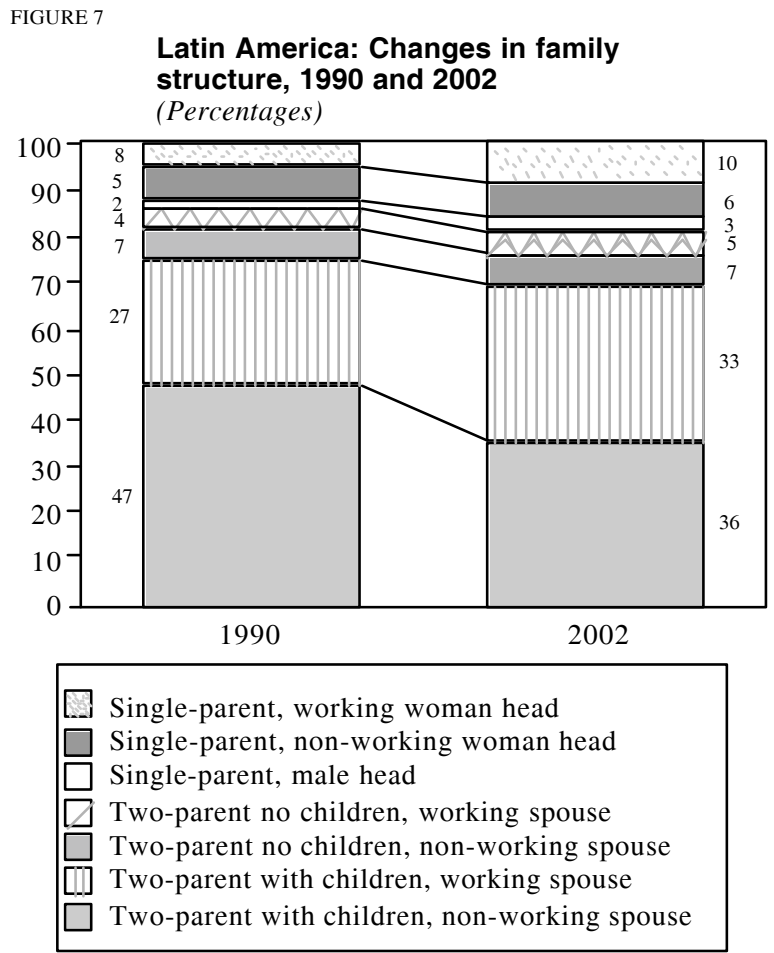

Source: Arriagada, 2005.

FIGURE 8

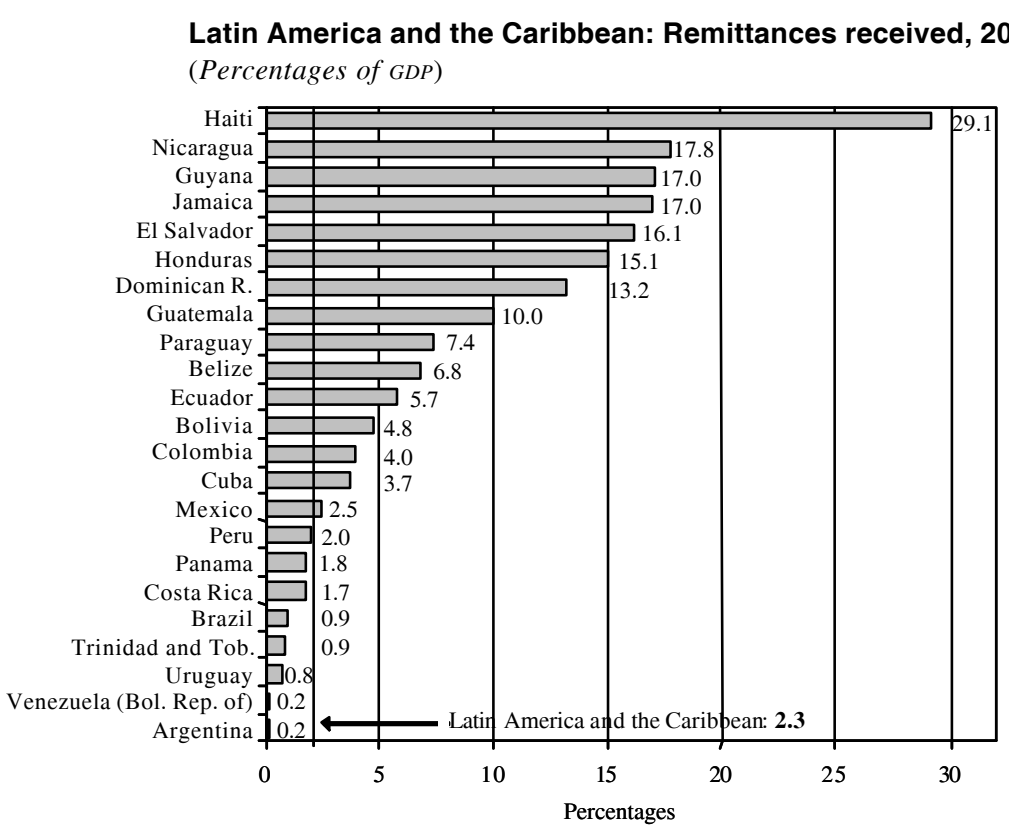

Source: ECLAC (2005c). 
FIGURE 9

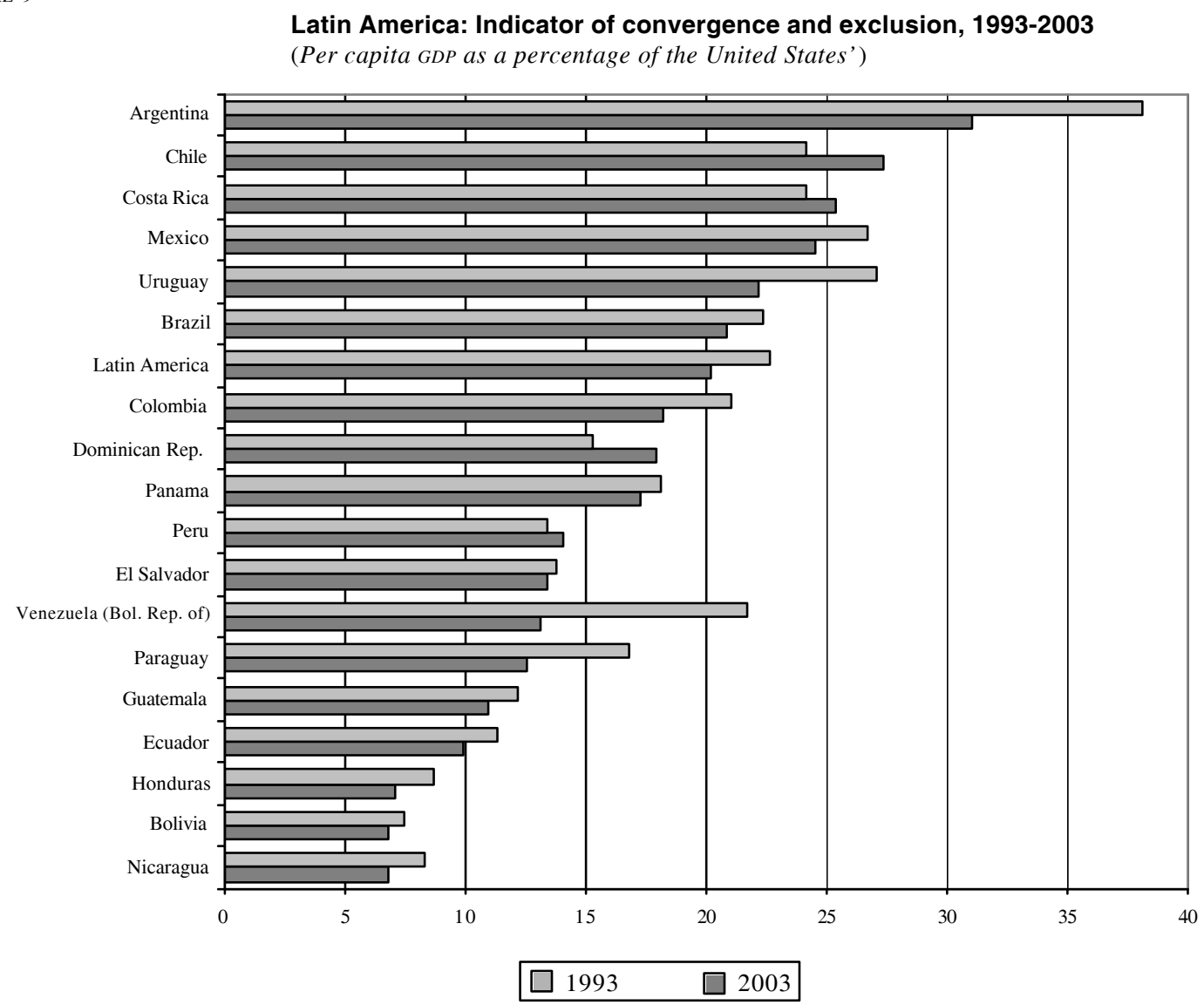

Source: ECLAC, on the basis of national accounts.

FIGURE 10

\section{Latin America: Population that would qualify for assistance under different categories of the HIPC initiative ${ }^{\mathrm{a}}$ \\ (Percentages of the population)}

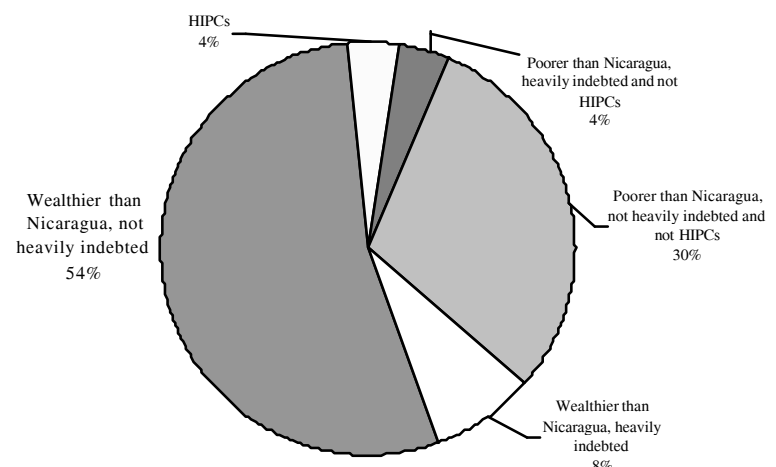

Source: ECLAC, on the basis of official information; Machinea and Uthoff (2005, p. 41).

${ }^{\text {a }}$ HIPC initiative $=$ Initiative to reduce the debt of heavily indebted poor countries.

\section{Anti-poverty efforts are not succeeding}

A fourth characteristic of the region is that, with development occurring only slowly during the 1990s, the limitations of the welfare State and of the most vulnerable households' survival strategies have prevented anti-poverty efforts from having any significant success. Indeed, while it is estimated that remittances have helped to reduce the incidence of poverty in recipient households and that State transfers have also helped to alleviate it, the effect of these transfers on the incidence of poverty has ultimately been much smaller than that observed in developed countries, and poverty levels are still not back down to the levels seen in years prior to the debt crisis (figures 11 and 12).

For the region as a whole, in fact, the incidence of poverty displayed a ratchet effect at one stage, since poverty-output elasticity was much greater in the recessionary phase than in the subsequentGDP recovery 
FIGURE 11

\section{Latin America (11 countries): Impact of remittances on poverty and indigence rates in recipient households, around $2002^{a}$}
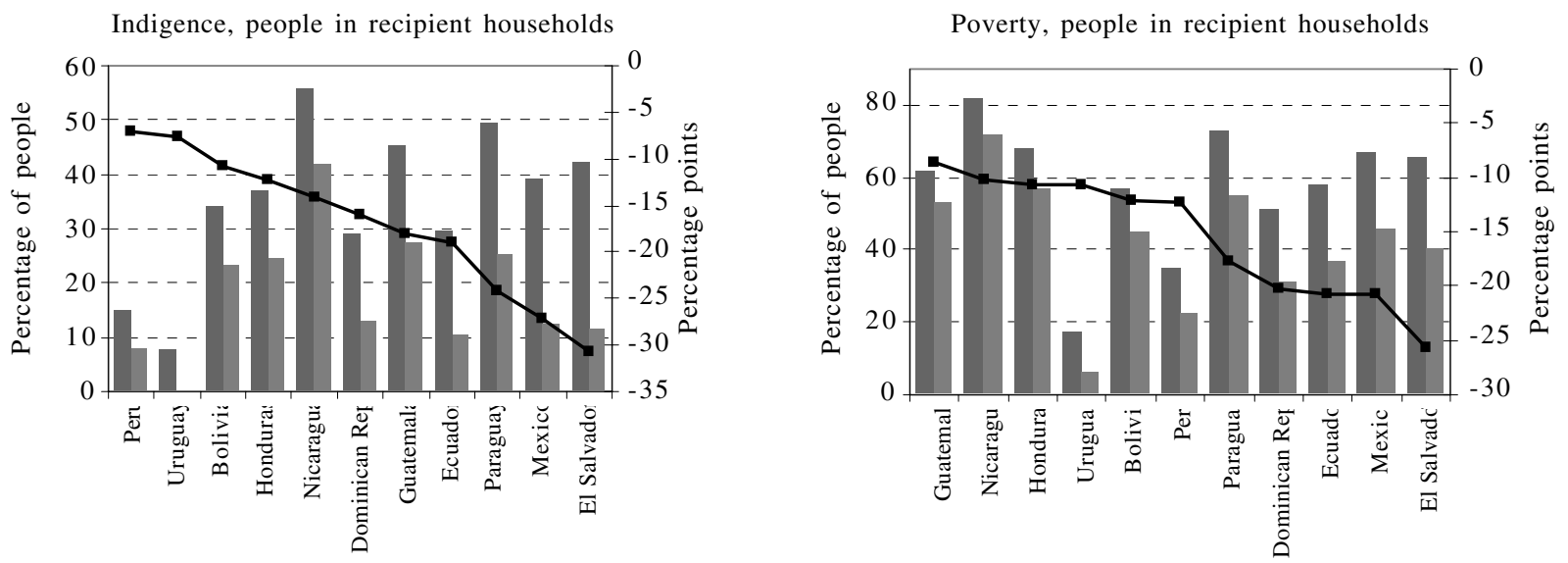

Source: ECLAC (2005c).

${ }^{\text {a }}$ Urban areas only in Uruguay and Ecuador

FIGURE 12

Latin America and OECD: Effects of State transfers on relative poverty
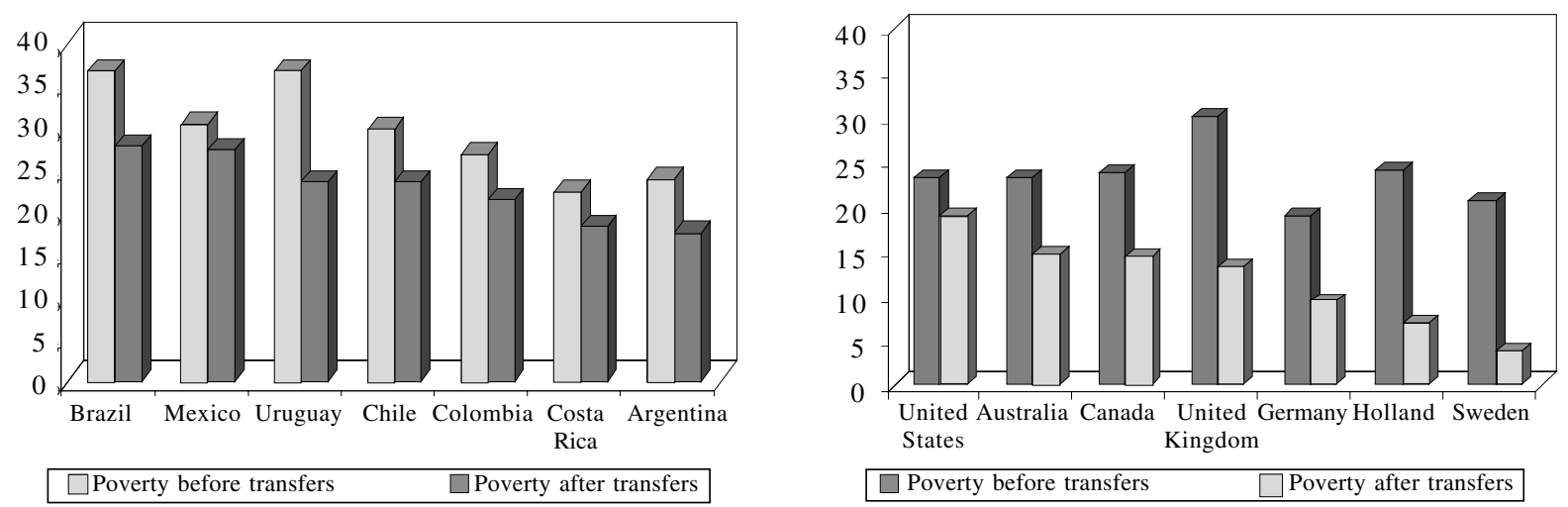

Source: For Latin America, prepared by the author using data from the household surveys available (in Uthoff and Ruedi, 2005). For the OECD countries, Smeeding and Ross (2001).

phase during the 1990s. Although this effect disappeared with the most recent crises, it left the incidence of poverty at a level much higher than that of 1980, even though the region's per capita GDP was almost 12\% higher (figure 13).

What emerges from the above is that the life cycle theory on which pension systems are based needs to be questioned in the region, since this theory relies on the supposition that all workers ought to be saving during the active phase of their life cycle and then dissaving during the phase of retirement in old age (figure 14).
Doubt is cast over this supposition by at least three factors: (i) a high proportion of the population live in poverty with unstable, insecure jobs, many immediate needs and a high discount rate that limits their long-term saving capacity; (ii) a growing proportion of women are having to head single-parent households or supplement their husband's income in order to subsist, thus breaking with the formula whereby the man is the provider and the woman looks after the house, but without doing away with the duality of roles in this latter task, so that it is harder for women to hold down stable employment; and 
FIGURE 13

Latin America: Incidence of poverty and gross domestic product per inhabitant

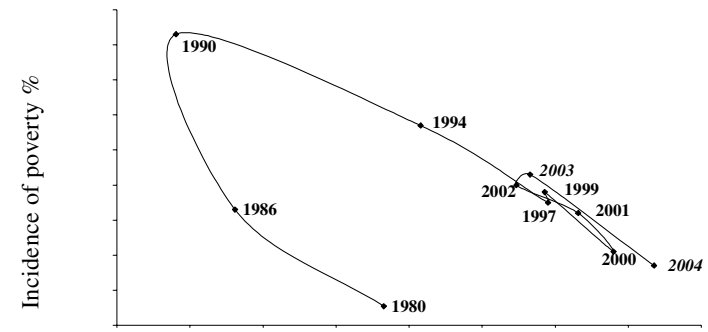

Source: ECLAC (2004a). The poverty figures for 2003 and 2004 are projections.

(iii) a growing proportion of workers are finding sporadic employment and do not have the income stability assumed by the life cycle theory.

In short, as figure 15 illustrates for the case of Chile, contributory models tend to display a low density of contributions, reflecting both the desire or need to remain inactive in order to take care of the home and the incidence of joblessness, uncertain employment and low
FIGURE 14

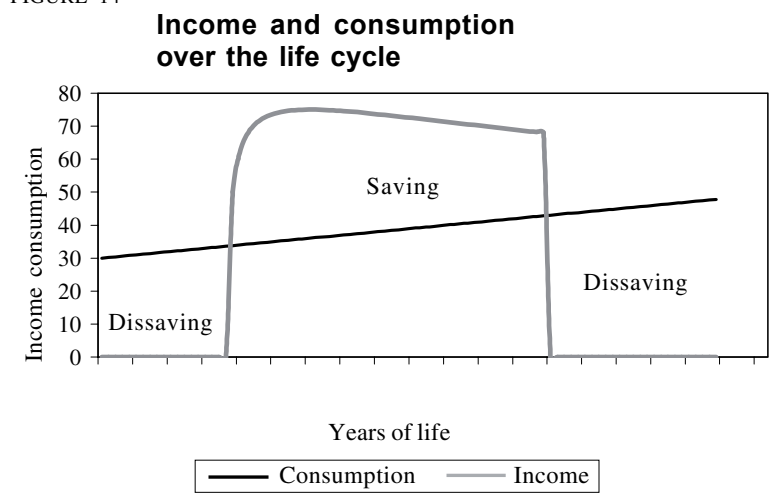

Source: Prepared by the author.

incomes; all this means that participation in contributory systems reproduces the inequities of the labour market and of society as a whole. As a result, only those who are able to find stable, well-paid employment will ultimately receive decent benefits. Since the great majority are not in that situation, these standard models will leave a large proportion of the population without decent pensions, especially women and those on low incomes.

FIGURE 15

Chile: Members paying into the pension system, by sex, age and poverty status ${ }^{a}$
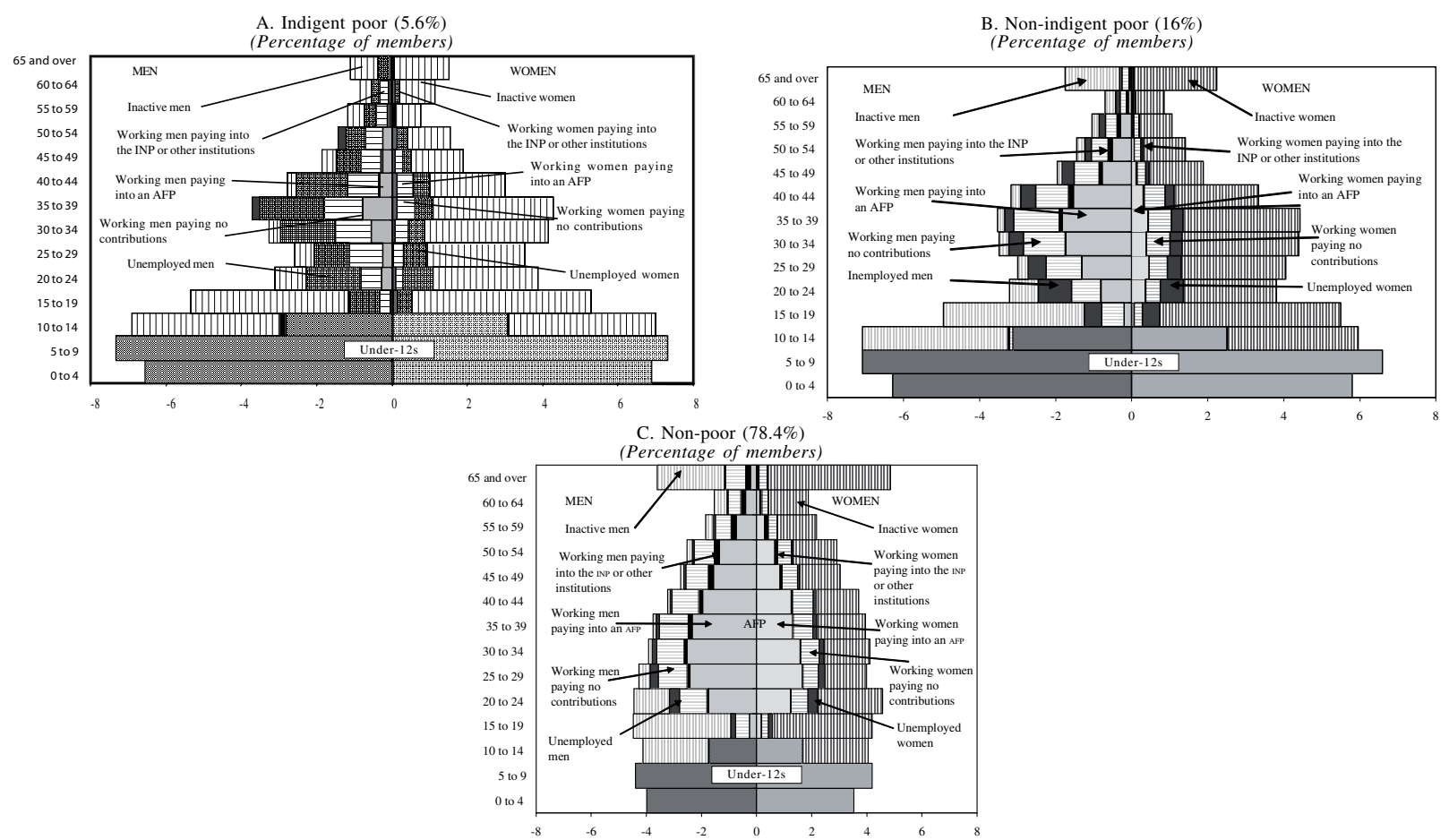

Source: Special tabulations based on the National Socio-economic Survey (CASEN, 1998).

${ }^{\mathrm{a}}$ INP = Instituto de Normalización Previsional (State social security agency); AFP = pension fund management company. 


\section{IV}

\section{Pension system reforms}

The design of pension systems and the reforms made to them have tended to overlook the social and distributive component that is required if a financing system is to meet the needs of the elderly poor. Instead, the focus has been on the contributory component, which has also been required to perform economic functions such as buttressing the solvency of the public sector, generating financial saving and assisting the development of the capital market, while also reducing costs in order to make labour more competitive.

The financial mechanism traditionally used to manage contributions and turn them into benefits has been a pay-as-you-go system based on graded average premiums, including rules to establish an intergenerational saving contract and a fund to cover likely risks of disablement and death, plus reserves for anticipated demographic changes. Non-contributory pension systems, where they exist, are financed out of general taxation and transfers (Mesa Lago, 2004 and 2000).

Unfunded systems have been criticized for a number of reasons, among them: (i) the administration of saving funds for events that are certain, such as old age, differs significantly from that of insurance funds for likely events (sickness, disablement and premature death); (ii) financing by intergenerational distribution cannot cope with significant demographic changes like those accompanying the rapid ageing of the Latin American population; ${ }^{6}$ (iii) these funds are clearly vulnerable to "political use" of their resources, since there has always been the possibility that governments might borrow from them for laudable public policy financing purposes, but without always ensuring the risk-return balance required to protect the reserve funds established to cover long-term benefit payments; (iv) the nature of system contributions and their relationship to benefits create scope for large crosssubsidies that lack transparency, do not always serve

\footnotetext{
${ }^{6}$ These are due to the rapid demographic transition which, since the mid-1960s, has translated into a large decline in fertility. Along with gradually rising life expectancy, the drop in fertility has led to significant changes in the age structure of the population that are affecting the ability of unfunded systems to maintain a proper financial balance between contributors and beneficiaries.
}

the interests of solidarity, and can affect the solvency of the system.

These four weaknesses of unfunded systems are at the heart of the arguments used by international financial institutions ${ }^{7}$ to urge the need for structural reforms, as opposed to traditional parametric reforms designed to introduce the actuarial adjustments that system solvency requires. Inspired by the neoliberal pension model developed under the military regime in Chile, these institutions promoted structural reforms whose aim was to establish a strict connection between individual effort and benefits by turning contributions into saving deposit instalments kept in individual retirement accounts under the control of pension fund management companies (AFPs) which manage investments in accordance with the rules laid down by a supervisory body. Unlike the intergenerational contract, whereby the contributions of current workers financed the benefits of current retirees, the neoliberal model introduces an individual contract in which the worker's pension is financed out of the "pot" which he or she succeeds in building up, namely the sum of lifetime contributions, duly capitalized; in this case, it is the actual worker who bears the risks of demographic change, in the form of higher life expectancy at retirement, and the financial risks of capitalization over his or her lifetime.

Not all the countries have made reforms of this type, however. Three types of reform can currently be distinguished: (i) parametric reforms, with notional defined-contribution models to the fore; (ii) structural reforms; and (iii) reforms that supplement current systems with additional saving mechanisms.

By strengthening the link between a member's contributions and benefits, even going so far in the extreme case as to employ a financing mechanism whereby these are managed in individual saving accounts, systems have experienced all the consequences warned of in the previous section: the pension fund markets that developed have proved hard to regulate, and the solutions adopted have tended to reproduce inequalities instead of counteracting them.

\footnotetext{
${ }^{7}$ See World Bank (1994).
} 


\section{Structural reform options}

The design of pension systems in Latin America was heavily influenced by the "social insurance" developed in former times by Chancellor Bismarck in Germany, which established protection for workers against the risks of old age, disablement and sickness. ${ }^{8}$ The most striking feature of such systems as applied in Latin America has always been their low coverage, chiefly owing to the informal nature of employment, now compounded by increasing job instability and insecurity because of the growing vulnerability of productive enterprises in the context of globalization (ECLAC, 2004b).

In its evaluation of the need for reforms in the early 1990s, and in view of rapid population ageing, ECLAC drew attention to the lack of progress in expanding coverage and warned of the pressure this would place on the fiscal accounts once the State took responsibility for relieving poverty in old age (ECLAC, 1991). ${ }^{9}$ It also emphasized that countries replacing their financing mechanisms would have to cope with enormous fiscal transition costs. ${ }^{10}$

Despite these warnings, reform models focused on the contributory components, opting between alternatives within six broad areas: (i) the importance of member contributions as a source of financing; (ii) the link between benefits and individual effort; (iii) the mechanism for administering financing; (iv) State involvement in system management; (v) compulsion; and (vi) the role of the private sector. Table 1 summarizes the options available to reformers and the alternatives adopted in two extreme models: Chile's, centred on the construction of a contributory individual capitalization pillar, and New Zealand's, centred on the construction of a non-contributory pillar with universal citizen entitlements.

TABLE 1

Chile and New Zealand: Reform options and extreme alternatives

\begin{tabular}{|c|c|c|}
\hline $\begin{array}{l}\text { System design } \\
\text { options available }\end{array}$ & $\begin{array}{l}\text { Options adopted in the design } \\
\text { of the Chilean model }\end{array}$ & $\begin{array}{l}\text { Options adopted in the design } \\
\text { of the New Zealand model }\end{array}$ \\
\hline Contributory & Yes & No \\
\hline Benefits & Defined contributions & Defined benefits \\
\hline Financial administration & Individually funded & Unfunded \\
\hline Management & Private & Public \\
\hline Compulsion & Employees & Citizen right \\
\hline Role of the State & $\begin{array}{l}\text { Market regulation } \\
\text { Market supervision } \\
\text { Distribution }\end{array}$ & Promotion of voluntary private-sector saving \\
\hline
\end{tabular}

Source: Prepared by the author on the basis of St. John and Willmore (2001).

\footnotetext{
${ }^{8}$ Originally, social insurance systems were based on compulsory contributions from employers and workers and a regulatory role for the State. Following the creation of the International Labour Organization in 1919, this type of insurance was established as a fundamental protection instrument for workers and their families, but was applied only to certain categories of workers. The concept was then extended in the United States (1935) and New Zealand (1938) to include elements of protection for the excluded and combat poverty, and the term "social security" began to be employed. This modernized concept was the one used by Beveridge between 1942 and 1946 as an instrument to combat poverty in Great Britain, so that contributory social insurance, social assistance for the poor and excluded and supplementary forms of voluntary insurance all came to form part of social security. These concepts and definitions have been enshrined in a variety of declarations on international social security law (Mesa-Lago, 2004).
}

${ }^{9}$ Also highlighted at that time were institutional weaknesses affecting the implementation of saving systems, owing to the fragility of macroeconomic regimes and shortcomings in regulation, oversight and development both in the pension fund industry and in capital and insurance markets (Held, 1994; ECLAC, 1996, chapter 10). Early warning was given of the lack of organizational regulation and public policies to prevent the formation of financial conglomerates in the pension fund management market and to turn financial saving into real investment (Arrau, 1994 and 1996; Larraín, 1996).

${ }^{10}$ See Holzmann (1997), ECLAC (1998) and Bravo and Uthoff (1999). Different interpretations and implications of these evaluations can be found in Uthoff (1995), ECLAC (2000, chapter 4), Jiménez and Cuadros (2003), Mesa-Lago (2004) and Titelman and Uthoff (2005). 
A number of elements should be taken into account before one or other of the extreme options is adopted. Two of them are crucial to the economics of the process. First, if an individual capitalization pillar prevails, the system will suffer from a lack of solidarity among members, since contributions are individually-owned saving instalments used exclusively to calculate the benefits of the member concerned. Second, when an unfunded financing mechanism is replaced by the new method of capitalization in individual accounts, the transition costs can be huge. The new system will have to pay for the benefits of retired members, the benefits accruing to current members because of rights acquired in the old system, and benefits explicitly guaranteed by the system, such as pensions for the armed forces, minimum pensions and welfare pensions. With the old system run on an unfunded, graded average premium basis, its reserve funds can be used to meet this expenditure if the social agreement under which the transition takes place so permits.

High transition costs and the loss of solidarity are consequences of the choices made with the Chilean model. An earlier study estimated the present value of the deficits the State would have to incur to cover these costs in a scenario where different countries opted for a Chilean-style reform (Bravo and Uthoff, 1999). For a number of countries this value was in excess of $200 \%$ of GDP, which was why they held back from a reform of this nature and opted for other models that will be discussed further on. In the Chilean case, indeed, it is now universally recognized that the reform has cost the government more than $5.5 \%$ of GDP a year for a period of 25 years and that it will take several years yet to pay for all the transition costs, guarantees and accumulated deficits (figures 16 and 17).

Nor is the option of establishing a universal citizen's pension beyond the financial requirements of the State. Following St. John and Willmore (2001), it is possible to distinguish two variables determining the amount of this type of pension as a percentage of GDP: the first is the number of beneficiaries as a percentage of the total population, and the second is the amount of the benefit as a percentage of the

FIGURE 16

Latin America and Haiti: Implicit pension debt (Percentages of GDP)

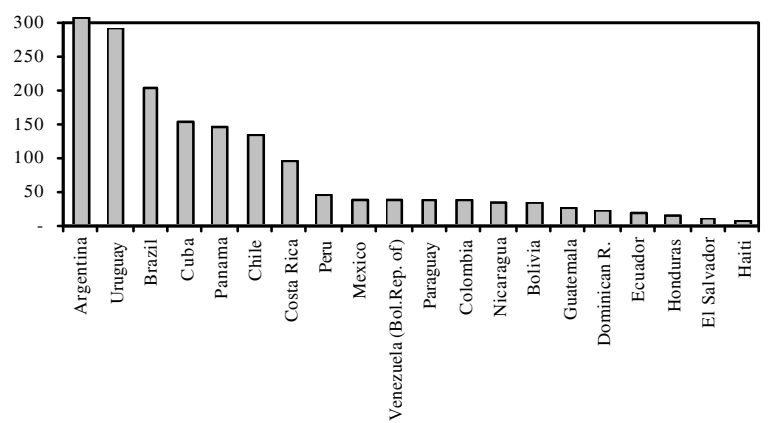

Source: Bravo and Uthoff (1999, p. 88).

FIGURE 17

Chile: Total pension deficit

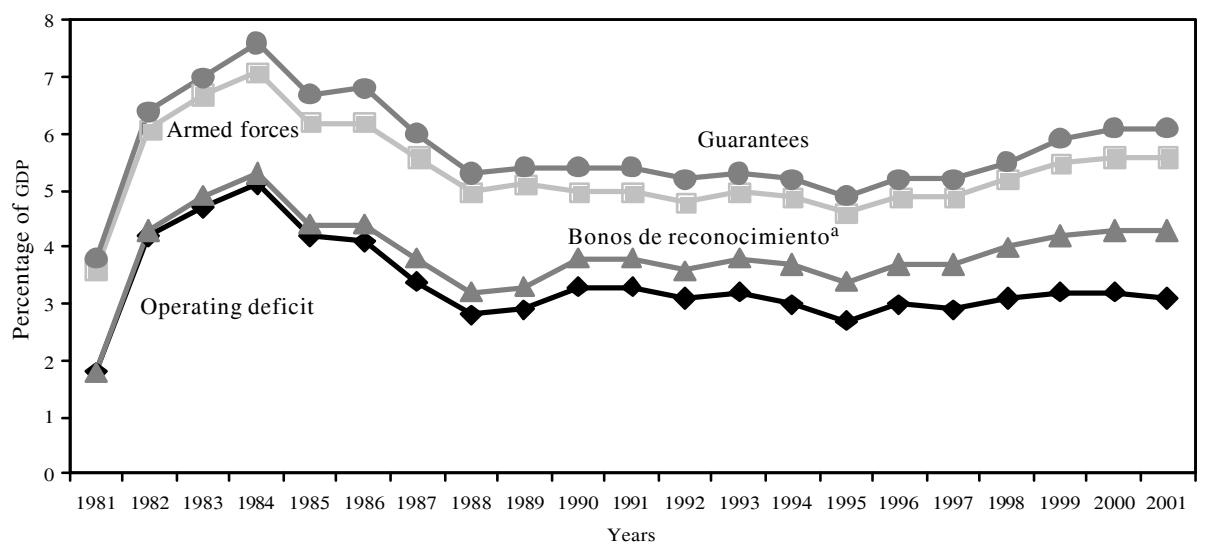

Source: Arenas de Mesa (2000).

a Bonos de reconocimiento: Certificates entitling members of the old system to transfer entitlements to the new one. 
country's per capita GDP. The result is extremely sensitive to this latter variable, which means that the amount of the universal benefit and its source of financing (income or consumption taxes) will be crucial issues in the public finance debate. In any event, a social agreement will be needed.

\section{The types of reform adopted}

A number of countries in Latin America opted to reform their contributory systems: they created a stronger link between contributory efforts and benefits for each individual; introduced individual capitalization as a financing criterion, wholly or in part; and allowed pension funds to be managed privately. These are known as structural reforms, and the following should be distinguished: (i) those that, like Chile's, completely replace the old pay-as-you-go public-sector system with an individual capitalization system, in so-called substitution models (Chile, Bolivia, El Salvador, Mexico, ${ }^{11}$ Dominican Republic); (ii) those that supplement the unfunded public system with an individual account capitalization component, in socalled mixed models (Argentina, Ecuador, Uruguay, Costa Rica); and (iii) those that allow members to choose between the two, in so-called parallel models (table 2). Of the parametric reforms, attention should be drawn to Brazil's reform of the General Social Security Regime (Regime Geral de Previdência Social (RGPS)); this reform establishes a capitalization rule that turns the unfunded system into a defined-

${ }^{11}$ With the Mexican Social Security Institute (IMSS).

TABLE 2

Latin America: Pension reform models and their characteristics, 2004

\begin{tabular}{lcccc}
\hline $\begin{array}{l}\text { Model, country and } \\
\text { starting date for reform }\end{array}$ & System & Contributions & $\begin{array}{c}\text { Benefits } \\
\text { Financial } \\
\text { regime }\end{array}$ & $\begin{array}{c}\text { Management } \\
\text { With structural reforms }\end{array}$ \\
\hline
\end{tabular}

Substitution model

Chile: May 1981

Bolivia: May 1997

Mexico: September 1997

El Salvador: May 1998

Private Defined Undefined FIC $^{\mathrm{a}} \quad$ Private $^{\mathrm{b}}$

Dominican R.: 2003-2006

Parallel model

Peru: June 1993

Colombia: April 1994

$\begin{array}{ccccc}\text { Public or } & \text { Undefined } & \text { Defined } & \text { Unfunded } & \text { Public } \\ \text { private } & \text { Defined } & \text { Undefined } & \text { FIC } & \text { Private }\end{array}$

Mixed model

Argentina: July 1994

Uruguay: April 1996

Costa Rica: May 2001

Ecuador: 2004

Public and

private

$\begin{array}{cc}\text { Undefined } & \text { Defined } \\ \text { Defined } & \text { Undefined }\end{array}$

Public Multiple ${ }^{\mathrm{c}}$

\begin{tabular}{|c|c|c|c|c|c|}
\hline \multicolumn{6}{|c|}{ With parametric reforms, or none } \\
\hline $\begin{array}{l}\text { Brazil (private Regime Geral } \\
\text { de Previdência Social (RGPS) }\end{array}$ & Public & Defined & Undefined & Unfunded or $\mathrm{CPC}^{\mathrm{b}}$ & Public \\
\hline $\begin{array}{l}\text { Brazil (others) } \\
\text { Cuba } \\
\text { Guatemala } \\
\text { Haiti }\end{array}$ & & & & & \\
\hline $\begin{array}{l}\text { Honduras } \\
\text { Nicaragua: } 2004 \\
\text { Panama } \\
\text { Paraguay } \\
\text { Venezuela (Bol. Rep. of })^{d}\end{array}$ & Public & Undefined & Defined & Unfunded or CPC & Public \\
\hline
\end{tabular}

Source: Mesa-Lago (2004).

${ }^{a}$ Full individual capitalization (FIC).

${ }^{\mathrm{b}}$ Collective partial capitalization (CPC).

\footnotetext{
${ }^{\mathrm{c}}$ Private, public or mixed.

${ }^{\mathrm{d}}$ Parametric reforms recently introduced or in progress.
} 
contribution system (Pinheiro and Paiva, 2000) with automatic parameter adjustments.

Evaluations of structural reforms are highly controversial. Some show these reforms as having positive effects on the economy (Corbo and SchmidtHebbel, 2003) and are used to promote their virtues. From the social protection point of view, however, evaluation results leave a good deal to be desired. Crucially, the coverage of contributory systems is still low and remains sensitive to the labour market, ${ }^{12}$ not only in private systems but also in systems that combine active contributors (to funded and unfunded schemes). The coverage of the social protection system stands at half the economically active population in Argentina, and in the region as a whole the weighted average has fallen from $38 \%$ to $27 \% .{ }^{13}$ In some countries that kept their public systems (Brazil and Panama), coverage has been between twice and four times as high as in seven countries that carried out structural reform.

Given the importance of formal paid work for expanding coverage, it is possible to group the countries by their welfare State gap. ${ }^{14}$ The percentage of older adults stating that they have retirement income in household surveys varies significantly between these groups of countries (figure 18). ${ }^{15}$ Inertia is observed in insurance coverage, since in countries where the proportion of the older adult population currently covered is low, so too is the proportion of wage earners currently paying towards their future pension (table 2). Unless substantial changes are made to current systems (to improve coverage), the problem of old-age poverty will remain. ${ }^{16}$

It should come as no surprise, then, that even the World Bank, long a fervent promoter of neoliberal

FIGURE 18

Latin America: Percentage of older adults receiving retirement income, by age and country group

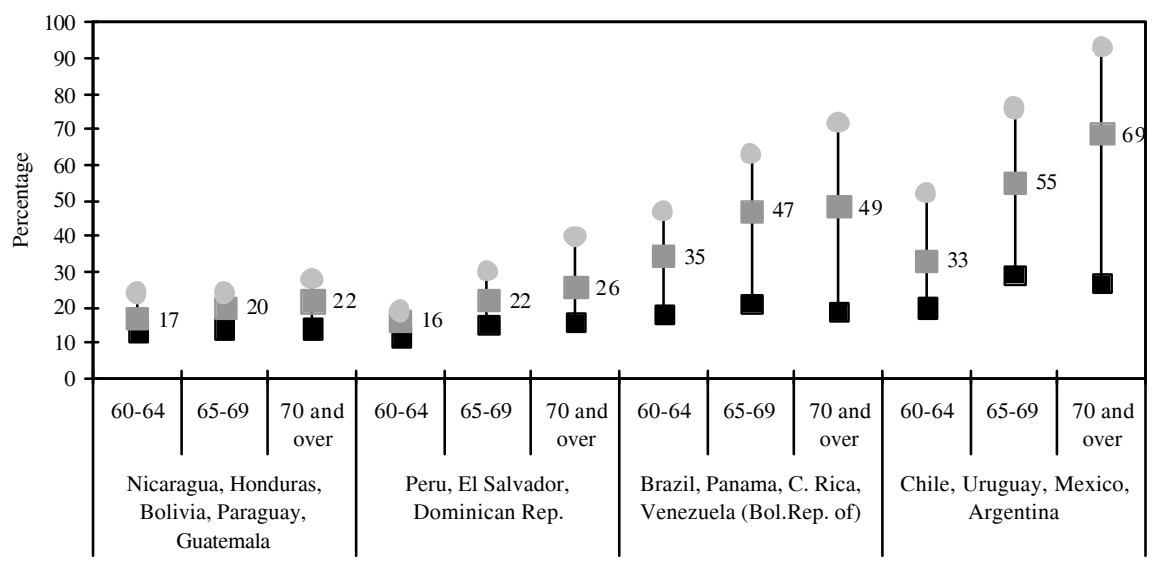

- Lowest $\square$ Average $\longrightarrow$ Highest

Source: Special tabulations of the household surveys available from the respective countries, 2000-2002.

\begin{abstract}
${ }^{12}$ It has been recognized, even by the World Bank, that extending coverage (especially among informal workers) by creating greater incentives for participation with the creation of a close link between contributions and pension amounts achieved a modest initial increase in two countries (Chile and Mexico), after which coverage stagnated at half the workforce in the richer countries and at an even lower level in the rest.

${ }^{13}$ The comparison is not perfect for all countries (Mesa-Lago, 2004), but there are two standardized series from Chile that confirm the downward trend: from $79 \%$ in 1973 and $62 \%$ in 1975 to 58\% in 2002 (Arenas de Mesa and Guzmán, 2003).

${ }^{14}$ While this indicator ascribes the same weight to each group of employees and assumes that every formal worker is fully employed, it does nonetheless show the difficulties society faces in meeting the needs of a large percentage of the population that does not participate in the labour market in a fully productive way.
\end{abstract}

\footnotetext{
${ }^{15}$ For formal workers to have more dependents does not necessarily mean that these dependents are needier and/or more vulnerable, given the multiplicity of family and institutional arrangements that exist to meet their needs and protect them from the risks they face. In those societies where demographic pressures are greater and the formal economy represented by their workers is limited, however, both the contributory capacity of the latter and the tax take available to the State for financing social spending are restricted.

${ }^{16}$ The measure of coverage for current workers overestimates the degree of protection that families will have, since it only refers to wage earners. The coverage problem is thus even more serious from the point of view of contributions, which means there is scope for non-contributory pensions (Fajnzylber, 2005).
} 
reforms to increase coverage, and indeed of pension reforms that promote individual saving, should have recognized in two reports ${ }^{17}$ that reforms concentrating exclusively on contributory subsystems will leave many citizens excluded and in poverty once they reach old age. Accordingly, one of these reports calls for the establishment of a tax-financed social protection network for old age, while the other calls for the construction of optional schemes to support families and the excluded.

In countries like Panama and Uruguay, whose social security systems go back a long way and have high coverage, there are informal-sector wage earners ${ }^{18}$ who are excluded from contributory systems, something that ultimately represents a burden for the treasury and/or their families, since such people will look to government-guaranteed benefits or depend on their families to survive once faced with poverty in old age. The percentage contributing is greater in urban areas than rural ones and several times higher in high-income sectors than low-income ones. Coverage is below $10 \%$ in the poorest quintiles of the group of countries with the lowest incomes and the largest number of dependents per formal worker. The higher per capita income is, the greater coverage will be in the poorest quintiles of the country concerned (figure 19). ${ }^{19}$

FIGURE 19

\section{Latin America: Working urban residents paying into social security, by distribution quintile and country group ${ }^{a}$}
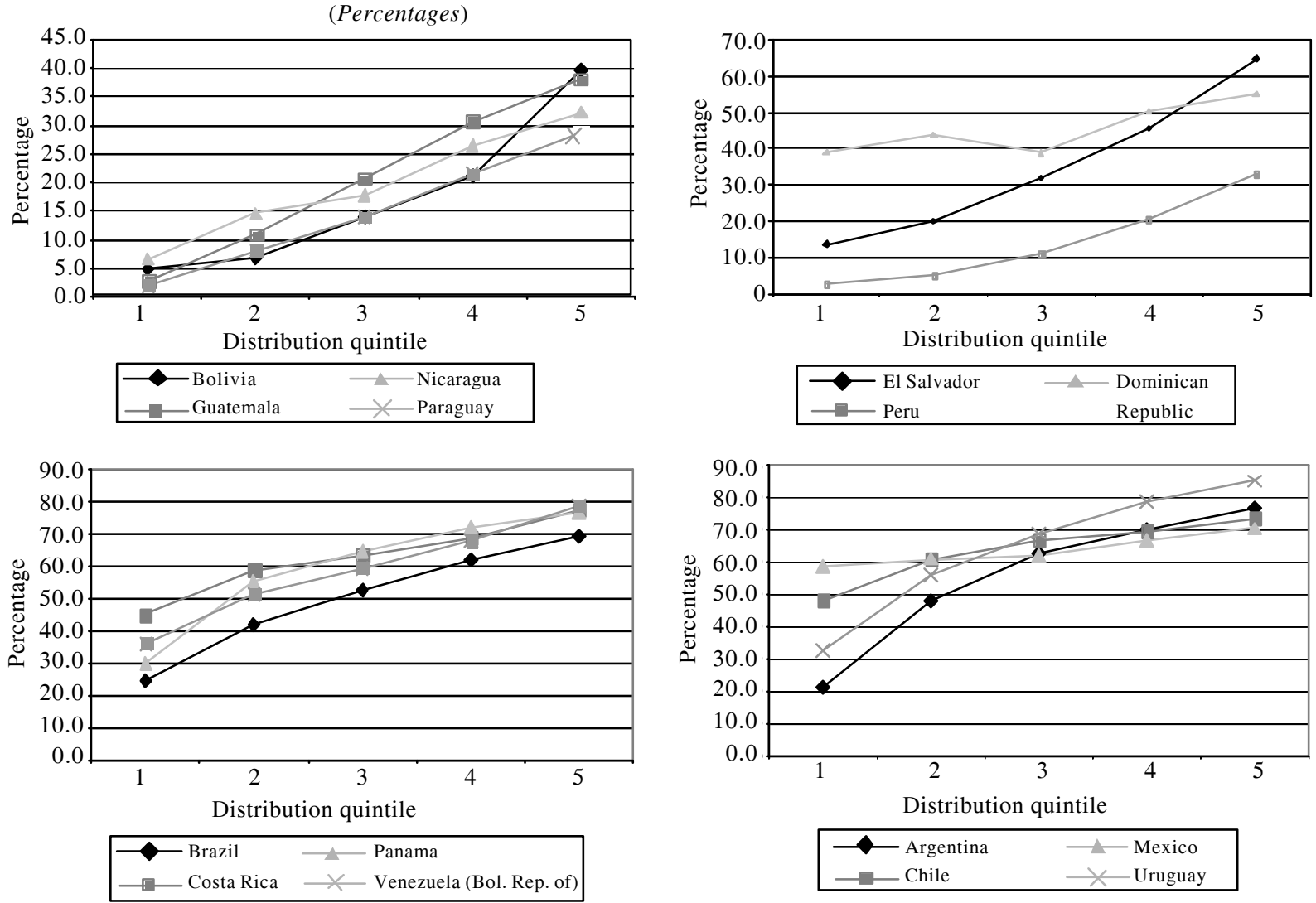

Source: Fajnzylber (2005).

${ }^{\text {a }}$ Ranked highest to lowest by formal worker dependency ratio.

\footnotetext{
${ }^{17}$ Gill, Packard and Yermo (2004); Holzmann, Hinz and others (2005).

${ }^{18}$ In smaller companies with a low capital/labour ratio and severe restrictions on access to credit and trade markets.

${ }^{19}$ More specific surveys (such as CASEN Chile) reveal that coverage among the working active population discriminates by income
}

stratum, sex and occupational category. Women are particularly unprotected (except insofar as they are treated as beneficiaries of their husbands' pensions), as are the unemployed, informal sector workers and the poorest. In highly unequal societies, contributory systems that lack a solidarity component will leave out all those who cannot save to finance their own pensions. 
The empirical literature on contribution density over the active life span concludes that, even among some of the countries with the highest pension coverage such as Uruguay, Argentina and Chile, membership density is far from sufficient to provide any real prospect of significant replacement rates for the covered population. ${ }^{20}$ In both Argentina and Chile, average contribution density is close to $50 \%$. The Uruguayan methodological study that is most comparable with the studies on Argentina and Chile shows that density is slightly higher in Uruguay $(60 \%)$ than in the other two cases; nonetheless, it is well below the $88 \%$ required for a "standard pension" ("jubilación común") at 60 , or even the $78 \%$ needed to retire with a pension at 65 (Bucheli, Forteza and Ferreira-Coimbra, 2005).

Given these important characteristics of system coverage, efficiency and equity, five main conclusions can be reached: (i) transition costs can ultimately be high, and this factor is so important that it has influenced the design of the reformed systems; (ii) the considerations of ethics and the principles of universality, integrality and solidarity that have to be taken into account in pension system design are diverse and very profound, and a wide consensus needs to be reached on these matters; (iii) all kinds of actors are affected by reforms, and there will be winners and losers among them, so they need to be consulted on each of the changes; (iv) privatization of system management involves major economic and financial interests, as well as changes in the social security management power structure, which means that technical arguments concerning competitiveness and efficiency need to be studied closely.

Lastly, there is a need to moderate the influence of international institutions in promoting a particular class of reforms, chiefly in order to restore solidarity elements. In particular, it is necessary to restore the role of the State in the regulation of the pension fund market and in the distributive aspects of the system. When individual account capitalization pillars are promoted, the principle of equivalence applied to each individual member turns member payments into private contributions to a defined-contribution individual saving account, thus depriving the system of any possibility of internal solidarity. In the absence of regulation in the individual saving accounts management market, the equivalence principle crowds out the solidarity principle. Were the latter applied, benefits for the poorest, the old and the sick could be financed out of the contributions of the better-off, the young and the healthy. By authorizing private management of pension funds in the way described, the State takes upon itself a fundamental responsibility for looking after the poor in old age, but without being able to use social insurance contributions to fund pensions. Specifically, the distributive function is separated from the (private-sector) management of social pension insurance, and the financing of each of these areas is separated as well.

\section{$\mathrm{V}$}

\section{The main results}

The region's experience with pension system reforms has yielded three principal results. First, the shift from unfunded systems to capitalization systems is no guarantee of greater physical capital accumulation; on the contrary, it generates major public saving requirements that have to be met. Second, the reforms are not generating enough incentives to increase population coverage; on the contrary, the structural factors limiting the contributory coverage of systems have loomed larger. Third, there is no magic formula for improving benefits: this can only be achieved if people save more and receive

\footnotetext{
${ }^{20}$ Fajnzylber (2005) reviews studies of the issue dealing with Argentina, Uruguay and Chile.
}

benefits for shorter periods, and this is linked to the efficiency with which savings are managed and the way benefits are adjusted to changes in life expectancy.

\section{Greater physical capital accumulation?}

In countries that created an individual capitalization pillar, physical capital has not increased in proportion to workers' contributions to their individual accounts. Crucially, workers' contributions are financial savings and need to be channelled into real investments, something that does not happen immediately but depends on the structure of the portfolio. Unless appropriate macroeconomic frameworks for long-term resource allocation have been established and there are structurally regulated and 
supervised institutions to ensure the proper working of the capital market, most portfolios will be composed of government bonds and bank deposits. A natural counterpart to the creation of individual accounts is the formation of a liability for transition costs in the form of current pensions, rights acquired by active members and the liabilities represented by guarantees.

These two tendencies place countries under serious constraints when it comes to turning pension saving into physical and non-financial capital accumulation. Given the high costs of transition, many countries chose not to replace the unfunded system in its entirety, and the percentage going to individual accounts is still low, so that the accumulated fund remains small as a percentage of GDP. Because of these same transition costs and long-standing deficits in both the public finances and, often, the pension system itself, in many countries the demand for funds by the State displaces private-sector demand for those same resources, the result being a high proportion of treasury bonds in the composition of portfolios.

In summary, the creation of individual account capitalization pillars generates a fiscal liability for the pension debt with which the old unfunded system operated, and likewise for benefits guaranteed to the armed forces and the poor in old age. The need to accept responsibility for current pensions, rights acquired under the old system by current contributors and benefits guaranteed to the armed forces and the poor (if there are constitutional guarantees) will demand an extraordinary commitment of government resources. If the government is unable to generate a primary surplus to meet this expenditure, it will end up by seeking resources from the very capital market it hopes to bring into being to fund long-term investment spending through capitalization (figures 20 and 21).

FIGURE 20

Latin America (10 countries): Funds under management, June 2005

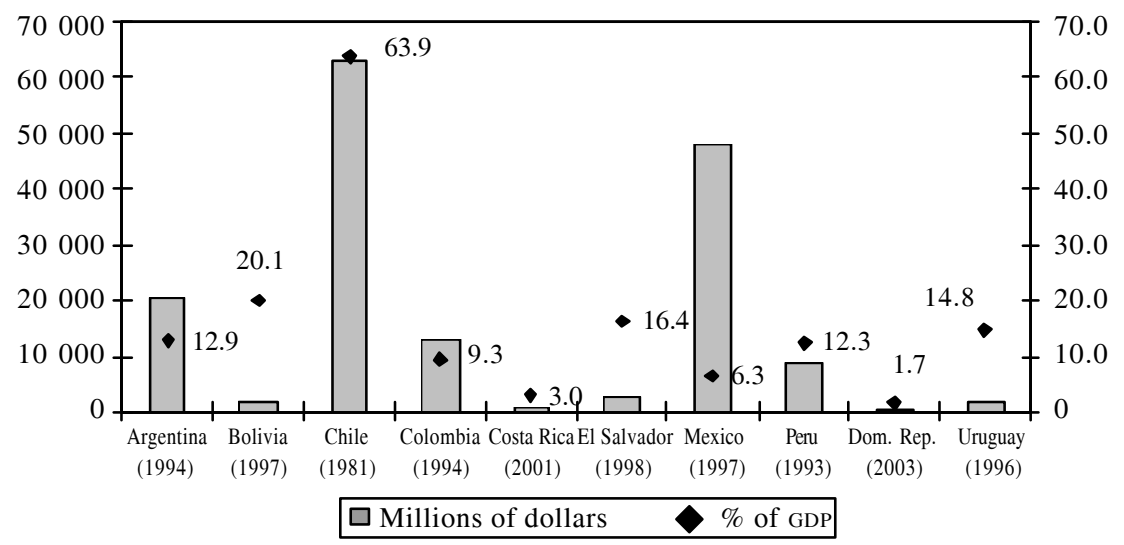

Source: International Association of Pension Funds' Supervisory Organisations (AIOS, 2005).

FIGURE 21

Latin America (10 countries): Pension fund composition, June 2005 (Percentages)

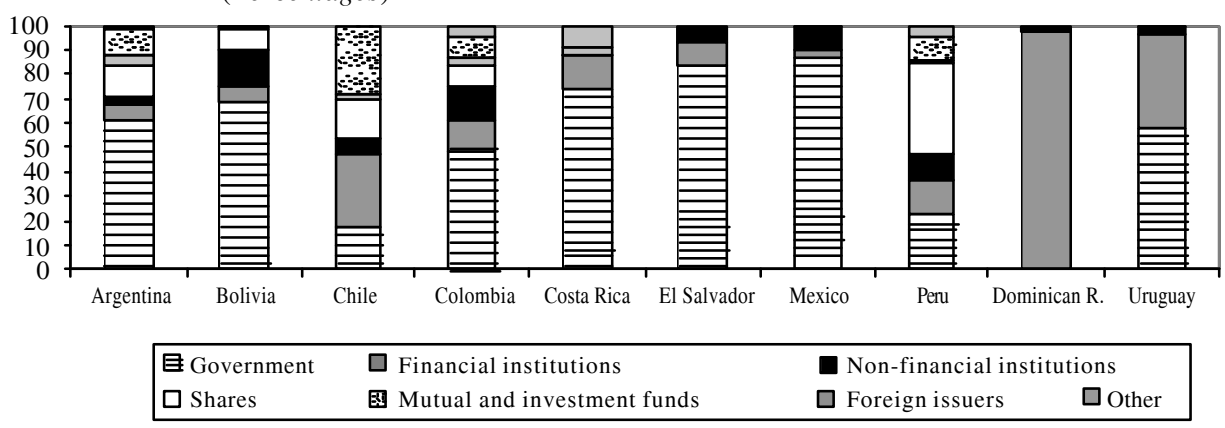

Source: International Association of Pension Funds' Supervisory Organisations (AIOS, 2005). 


\section{Greater coverage?}

Another worrying feature of the statistics on reformed systems is that they reveal a chronic gap between the number of system members and the number of contributors (figure 22). Effective coverage as measured by the proportion of working people actually paying into these systems remains low, and the existence of a wide gap between the numbers who have joined them at some point and the numbers paying in indicates that the density or regularity of system contributions is intermittent, and thus that the continuity of saving is irregular. All this may mean that the capital accrued by retirement is small, with major implications for benefit amounts, especially for those on low incomes and those who do not manage to contribute at an early age, so that capitalization does not work in their favour.

Faced with this evidence, a number of countries have initiated panel studies to examine the work and contribution record of members with a view to determining what replacement rate they will attain and whether they will be able to finance their own pensions or will qualify for State-guaranteed minimum and/or welfare pensions.

According to administrative data from different pension systems in Latin America, average contribution density is between $50 \%$ and $70 \%$. The average density of contributions during the working stage of life is several percentage points higher among men than among women. Densities are significantly greater in higher-income sectors (except between the ages of 18 and 25 , when many people are studying) than among lower-income groups. There is a tendency, particularly in the lowest stratum, for there to be a relatively low contribution density at the age of 21 but for the frequency of contributions then to increase gradually over the course of people's working lives (table 3 ).

All this suggests that systems which create closer links between contributions and replacement rates will tend to reproduce the inequities of working life, turning them into pension inequities without leaving any scope for compensatory subsidies between contributors within the system (ECLAC, 2002). The least protected groups (and women in particular) will receive dramatically lower pensions owing to the low relative density of their contributions and, in the case of the lowest quintiles, to the tendency to delay contributing until a later stage in working life. The density of contributions varies greatly between men and women, ${ }^{21}$ and this is the determining factor in women's long contribution gaps, attributable to the amount of

FIGURE 22

Latin America (10 countries): Pension system coverage, June 2005

(Thousands of members and contributors as a percentage of the economically active population)

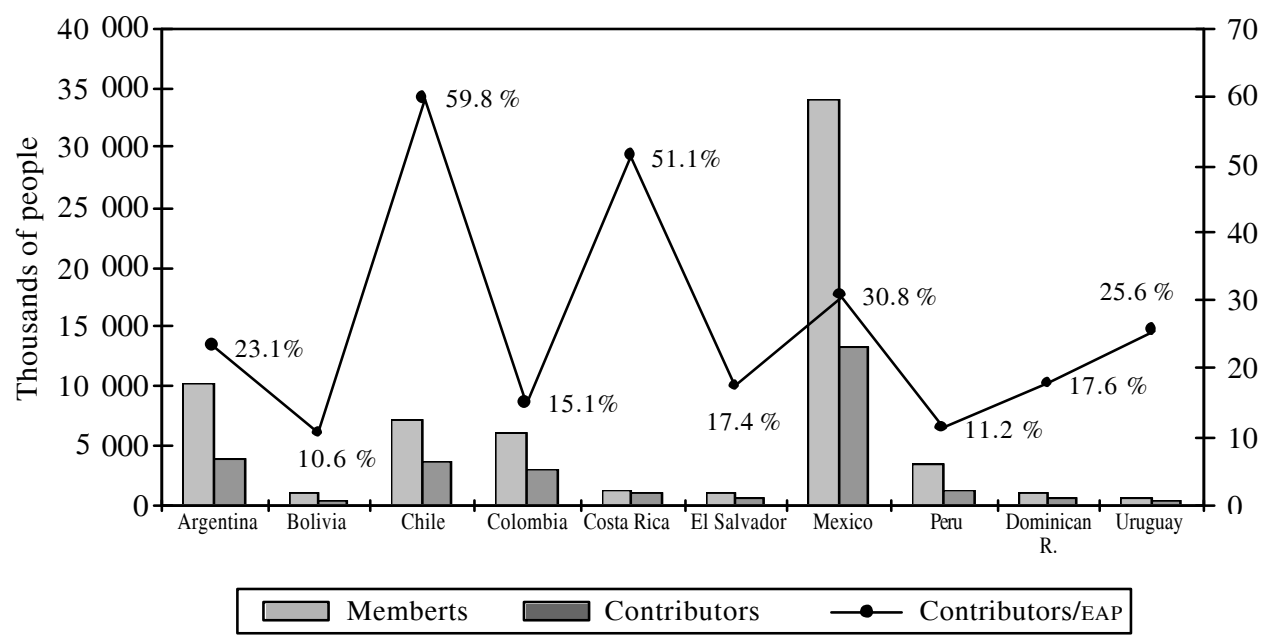

Source: International Association of Pension Funds' Supervisory Organisations (AIOS, 2005). ${ }^{21}$ In the bottom three quintiles of the female income distribution
(the lowest-income $60 \%$ ), women have average densities of
less than $40 \%$ throughout almost the whole of their lives, while even men in the second quintile have average densities that are systematically higher than this. 
TABLE 3

Argentina, Uruguay and Chile: How contributions are distributed

\begin{tabular}{|c|c|c|c|}
\hline Country & Study & Sample & $\begin{array}{c}\text { Average } \\
\text { density }(\%)\end{array}$ \\
\hline Argentina & Bertranou and Sánchez (2003) & $\begin{array}{l}\text { Employees, private sector, age } 25-65 \text {, } \\
\text { with at least one contribution between } \\
1994 \text { and } 2001 \\
\text { Administrative data }\end{array}$ & 49 \\
\hline \multirow[t]{2}{*}{ Uruguay } & Lagomarsino and Lanzilotta (2004) & $\begin{array}{l}\text { Private-sector employees with at least one } \\
\text { contribution during the second half of } 1996 \text {, } \\
\text { contribution density between } 1997 \text { and } 2003 \\
\text { Administrative data }\end{array}$ & $\begin{array}{l}70.2 \\
69.7(\mathrm{M}) \\
70.9(\mathrm{~W})\end{array}$ \\
\hline & $\begin{array}{l}\text { Bucheli, Forteza and } \\
\text { Ferreira-Coimbra (2005) }\end{array}$ & $\begin{array}{l}\text { Contributors to the Banco de Previsión Social (BPS) } \\
\text { with at least one contribution between } 1996 \text { and } 2004 \\
\text { Administrative data }\end{array}$ & $\begin{array}{l}60.8 \\
62.9(\mathrm{M}) \\
58.5(\mathrm{~W})\end{array}$ \\
\hline \multirow[t]{2}{*}{ Chile } & $\begin{array}{l}\text { Arenas de Mesa, } \\
\text { Behrman and Bravo (2004) }\end{array}$ & $\begin{array}{l}\text { Members of the AFP system with at least one } \\
\text { contribution between } 1980 \text { and } 2001 \\
\text { Information provided in the Social Panorama survey }\end{array}$ & $\begin{array}{l}52.4 \\
59.8(\mathrm{M}) \\
41.4(\mathrm{~W})\end{array}$ \\
\hline & Benstein, Larraín and Pino (2005) & $\begin{array}{l}\text { Members of the AFP system with at least one } \\
\text { contribution between } 1980 \text { and } 2001 \\
\text { Administrative data }\end{array}$ & $\begin{array}{l}53 \\
59(\mathrm{M}) \\
41(\mathrm{~W})\end{array}$ \\
\hline
\end{tabular}

Source: The authors cited in the table.

time taken up by childcare, personal responsibilities, pregnancy or housework ${ }^{22}$ (Marco, 2004; Reyes, 2004). This situation is very far removed from the contribution density requirements of the systems operating in the region (table 4).

\section{Better pensions?}

Moves towards defined contributions must meet three requirements if good pensions are to be ensured: (i) a high density of contributions, which, as the last section showed, is far from being the case; (ii) high returns for pension funds; and (iii) low administration costs.

Pension fund returns are subject to financial risks inherent in capital markets. Systems have been promoted on the basis of historical returns data for the Chilean model, which are in excess of $20 \%$ for those who have contributed throughout the 25 years of these funds' existence. Rates have been highly volatile,

\footnotetext{
${ }^{22}$ While this may be directly associated with a recognized phenomenon, the relatively low labour market participation of women in Chile, it needs to be considered in the debate about mechanisms for expanding coverage. Women are contributing significantly to a country's development by carrying out the activities referred to, even if these are not subject to formal contracts with pay and pension coverage.
}

however, with different levels of return for members who have been in the system at different periods. In other cases, moreover, it has proved impossible to insulate them from political risks, such as the systemic crisis caused by the abandonment of the Convertibility Act in Argentina (figure 23).

The fact is that the combination of different contribution periods with different levels of profitability can result in a low return for a member over the whole of his or her period of active membership. In combination with high commissions and a low contribution density, this can translate into an explosive situation for the financing of minimum and welfare pension guarantees if a large majority of members do not have the funds to finance their pensions. This possibility has been studied by the pension funds supervisor (Superintendencia de Administradoras de Fondos de Pensiones (SAFP)) in Chile.

Brazil's experience shows how important pension income can be in reducing the incidence of poverty as determined by market incomes among older adults. The country has a non-contributory pension programme with wide coverage in rural areas, and this has resulted in a sharp reduction in the incidence of poverty from the age of 60 onward. It can thus be seen that important distributive instruments are available 
TABLE 4

Latin America: Minimum densities required in public pension systems ${ }^{a}$

\begin{tabular}{|c|c|c|c|c|c|c|c|c|}
\hline \multirow[t]{2}{*}{ Country } & \multirow[t]{2}{*}{ Retirement option } & \multicolumn{2}{|c|}{$\begin{array}{l}\text { Minimum } \\
\text { retirement age }\end{array}$} & \multicolumn{2}{|c|}{$\begin{array}{l}\text { Minimum years } \\
\text { contributions }\end{array}$} & \multicolumn{2}{|c|}{$\begin{array}{l}\text { Minimum density at } \\
\text { retirement age }(\%)\end{array}$} & \multirow{2}{*}{$\begin{array}{c}\begin{array}{c}\text { Minimum } \\
\text { density }(\%)\end{array} \\
\text { Age } 20-65\end{array}$} \\
\hline & & Women & Men & Women & Men & Women & Men & \\
\hline Chile & Maximum replacement rate & 60 & 65 & 20 & 20 & 50 & 44 & 44 \\
\hline Bolivia & & 50 & 55 & 15 & 15 & 50 & 43 & 33 \\
\hline Mexico & & 65 & 65 & 9.5 & 9.5 & 21 & 21 & 21 \\
\hline El Salvador & & 55 & 60 & 25 & 25 & 71 & 63 & 56 \\
\hline Dominican R. & $\begin{array}{l}\text { Contributory } \\
\text { Subsidized contributory }\end{array}$ & $\begin{array}{l}60 \\
60\end{array}$ & $\begin{array}{l}60 \\
60\end{array}$ & $\begin{array}{l}30 \\
25\end{array}$ & $\begin{array}{l}30 \\
25\end{array}$ & $\begin{array}{l}75 \\
63\end{array}$ & $\begin{array}{l}75 \\
63\end{array}$ & $\begin{array}{l}67 \\
56\end{array}$ \\
\hline Nicaragua & & 60 & 65 & - & - & - & - & - \\
\hline Peru & & 65 & 65 & 20 & 20 & 44 & 44 & 44 \\
\hline Colombia & & 55 & 60 & 20 & 20 & 57 & 50 & 44 \\
\hline Argentina & & 60 & 65 & 30 & 30 & 75 & 67 & 67 \\
\hline Uruguay & $\begin{array}{l}\text { Standard retirement } \\
\text { Advanced-age retirement } \\
\text { Old-age pension } \\
\text { (non-contributory) }\end{array}$ & $\begin{array}{l}60 \\
70 \\
70\end{array}$ & $\begin{array}{l}60 \\
70 \\
70\end{array}$ & $\begin{array}{l}35 \\
15\end{array}$ & $\begin{array}{l}35 \\
15 \\
-\end{array}$ & $\begin{array}{l}88 \\
30\end{array}$ & $\begin{array}{l}88 \\
30 \\
-\end{array}$ & $\begin{array}{l}78 \\
33 \\
-\end{array}$ \\
\hline Costa Rica & $\begin{array}{l}\text { Normal } \\
\text { Early }\end{array}$ & $\begin{array}{l}65 \\
59.9\end{array}$ & $\begin{array}{l}65 \\
61.9\end{array}$ & $\begin{array}{l}20 \\
38\end{array}$ & $\begin{array}{l}20 \\
39\end{array}$ & $\begin{array}{l}44 \\
95\end{array}$ & $\begin{array}{l}44 \\
93\end{array}$ & $\begin{array}{l}44 \\
86\end{array}$ \\
\hline Ecuador & $\begin{array}{l}\text { Option } 1 \\
\text { Option } 2 \\
\text { Option } 3\end{array}$ & $\begin{array}{l}60 \\
65 \\
70\end{array}$ & $\begin{array}{l}60 \\
65 \\
70\end{array}$ & $\begin{array}{l}30 \\
10 \\
15\end{array}$ & $\begin{array}{l}30 \\
10 \\
15\end{array}$ & $\begin{array}{l}75 \\
22 \\
30\end{array}$ & $\begin{array}{l}75 \\
22 \\
30\end{array}$ & $\begin{array}{l}67 \\
22 \\
33\end{array}$ \\
\hline Brazil & & 60 & 65 & 15 & 15 & 38 & 33 & 33 \\
\hline Cuba & & 55 & 60 & $25^{\mathrm{b}}$ & $25^{\mathrm{b}}$ & 71 & 63 & 56 \\
\hline Guatemala & & 60 & 60 & 15 & 15 & 3 & 38 & 33 \\
\hline Honduras & & 60 & 65 & 15 & 15 & 38 & 33 & 33 \\
\hline Panama & & 57 & 62 & 15 & 15 & 41 & 36 & 33 \\
\hline Paraguay & $\begin{array}{l}\text { Option } 1 \\
\text { Option } 2\end{array}$ & $\begin{array}{l}60 \\
55\end{array}$ & $\begin{array}{l}60 \\
55\end{array}$ & $\begin{array}{l}25 \\
30\end{array}$ & $\begin{array}{l}25 \\
30\end{array}$ & $\begin{array}{l}63 \\
86\end{array}$ & $\begin{array}{l}63 \\
86\end{array}$ & $\begin{array}{l}56 \\
67\end{array}$ \\
\hline $\begin{array}{l}\text { Venezuela } \\
\text { (Bol. Rep. of) }\end{array}$ & & 55 & 60 & 14.5 & 14.5 & 41 & 36 & 32 \\
\hline
\end{tabular}

Source: Prepared by the author on the basis of Mesa-Lago (2004, tables 4 and 15).

a The table follows the order of presentation used by Mesa-Lago. First come the six substitution reform countries (Chile, Bolivia, Mexico, El Salvador, Dominican Republic and Nicaragua), followed by the two countries that adopted parallel schemes (Peru and Colombia), the four countries with mixed pillars (Argentina, Uruguay, Costa Rica and Ecuador) and seven countries with parametric reforms or none as of 2004.

b The requirement in Cuba is years worked.

for social pensions, but these require highly complex agreements (figure 24). In the case of non-contributory pensions, there are transfers in the form of subsidies from general taxation and, in certain cases, solidarity transfers of contributions to older adults. In the case of contributory pensions, there are transfers of savings to older adults from younger groups, whether these are contemporaries (unfunded system) or the actual member at an earlier stage in his or her life cycle (capitalization system).

A basic dilemma for pension systems are the complex relations between contributory and non- 
FIGURE 23

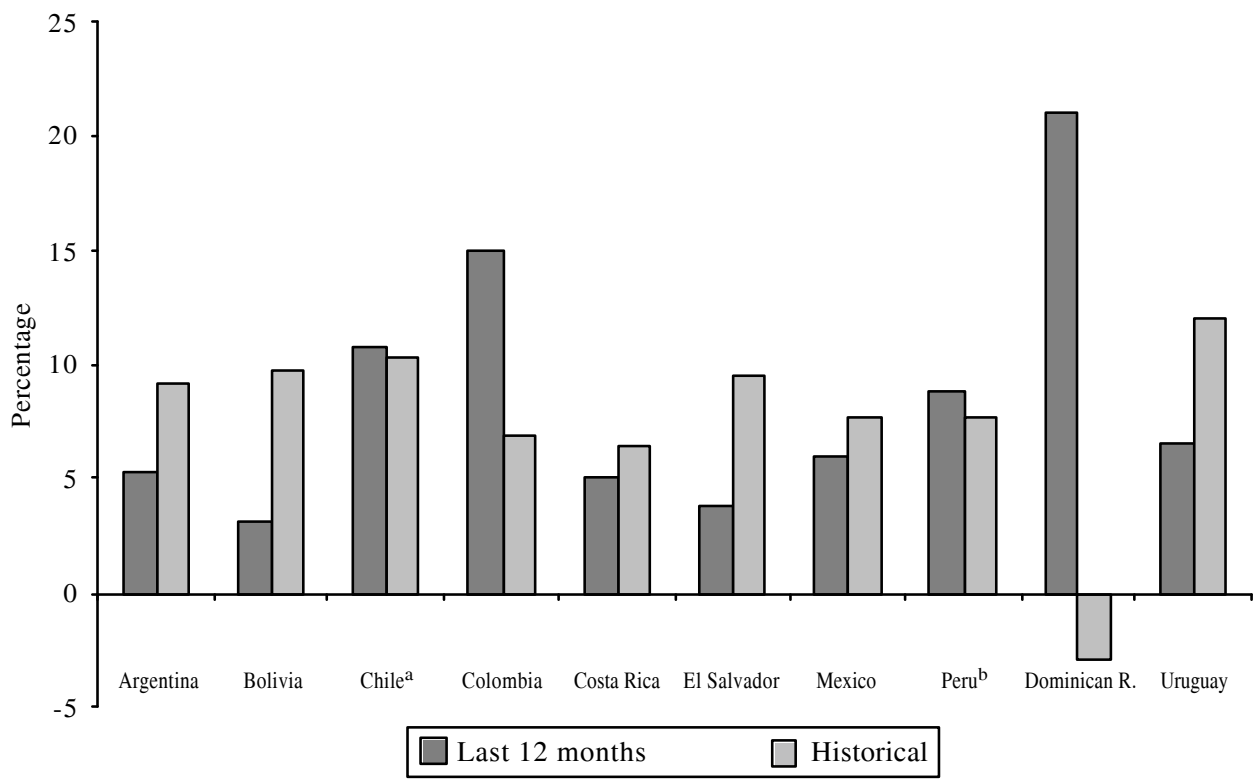

Source: International Association of Pension Funds' Supervisory Organisations (AIOS, 2005).

${ }^{\text {a }}$ Returns in Chile are for Fund C.

${ }^{\mathrm{b}}$ Historical returns correspond to the last 120 months.

FIGURE 24

\section{Brazil: The distributive role of social security, 1999 \\ (Poverty by age)}

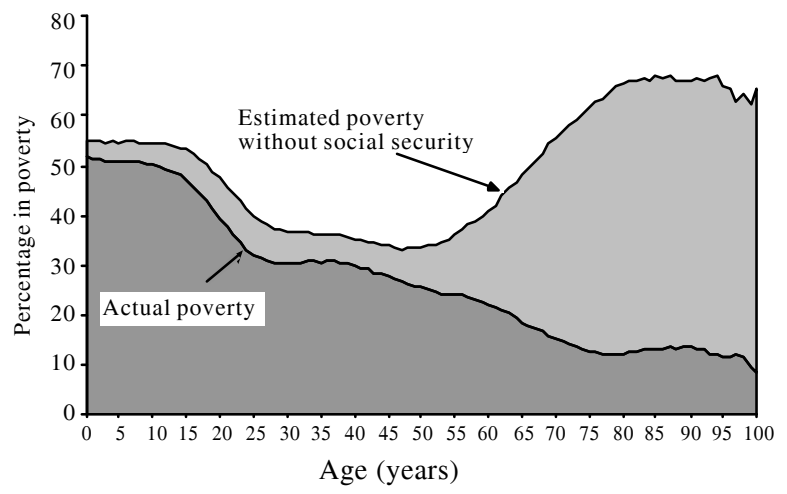

Source: National household survey (PNAD) for 1999, Institute of Applied Economic Research (IPEA)/Ministry of Welfare and Social Assistance.

contributory financing mechanisms. Both perform the functions required for a pension system, only benefits may be non-contributory or be linked to individual contribution efforts. It is possible that the certainty of receiving non-contributory benefits may reduce efforts to contribute to the system, in a kind of substitution effect, and thus generate perverse incentives for membership.

Although pension benefits can be very helpful in reducing the incidence of poverty among older adults, the distributive component has to be designed to complement the contributory component. Extreme cases do exist, like the New Zealand model, where all benefits are non-contributory and universal and there is a private-sector system of supplementary saving. At the other end of the scale is the Chilean model, which is contributory and involves capitalization in individual saving accounts managed by the private sector, with the State playing only a distributive role.

The potential for extending coverage via distributive policies that is held out by guaranteed welfare pensions needs to be handled very carefully, so that the incentive structure of the contributory component is not affected by the distributive role of the State, inside or outside the system. However, a lack of policies to guarantee stable employment will mean that contributory systems increasingly serve to select members by saving capacity and separate them into fully 
insured, underinsured and uninsured. For these last two categories of members, as the case of Chile shows, there will be increasing demands for explicit guarantees, in the form either of welfare pensions or of subsidized insurance for those who, having made an effort to contribute, fail to attain a "decent" pension (figure 25).

The Chilean model guarantees a minimum benefit level for all those who have paid into the system for 240 months and are unable to finance the value of that benefit once they reach retirement age. For everyone else, however, there is no guarantee even of a welfare pension, as these are subject to quotas set in the national budget and granted in accordance with strict targeting criteria.
Projections for Chilean defined-contribution systems show that, given reasonable assumptions for growth in per capita GDP, wages and pension fund returns, members who reach retirement age will be eligible for State-guaranteed minimum pensions whether or not they are poor. A larger and larger proportion will receive a State-guaranteed minimum pension. In this way, a system that reforms the contributory component will only benefit less than half of all workers, leaving a growing distributive burden to be borne by the State. According to estimates by the Chilean Ministry of Finance, this will mean enormous contingent liabilities (Arenas de Mesa, Llanes and Miranda, 2005).

FIGURE 25

Chile: Projections of different pension types for members of the AFP system ${ }^{a}$

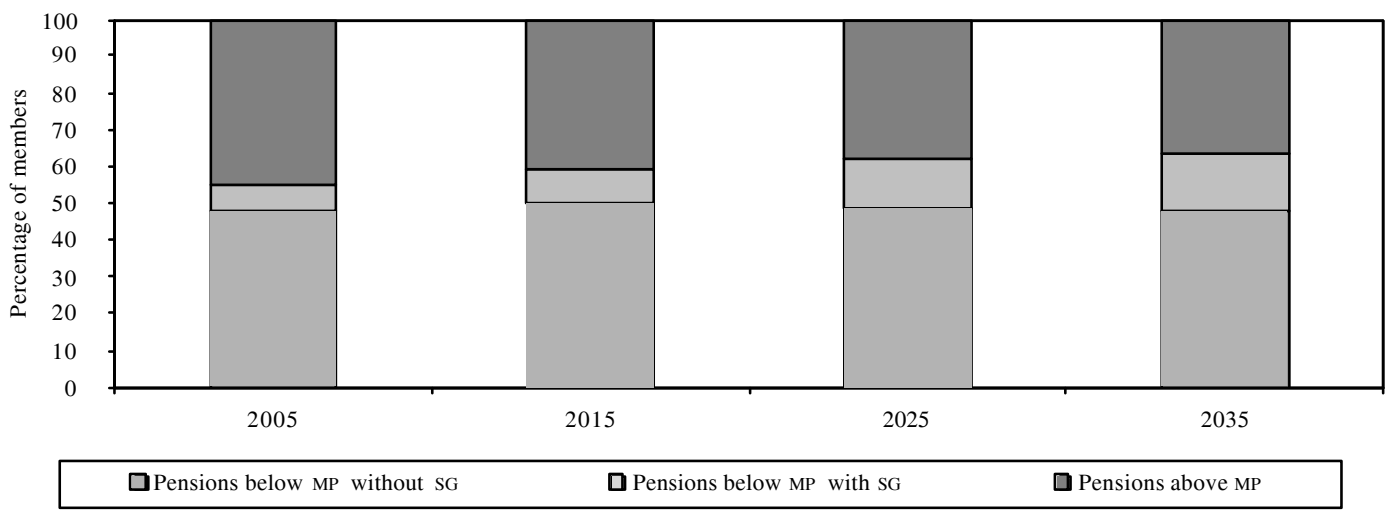

Source: Bernstein and Ruiz (2005).

${ }^{\text {a }}$ Pensions below the minimum pension (MP), with or without a State guarantee (SG), grow by $2 \%$, wages by $2 \%$ and returns by $5 \%$.

\section{VI}

\section{A social cohesion covenant}

The pensions issue involves complex interactions, and very substantive political and social agreements will be needed to resolve them. In particular, the rights agenda needs to be reconciled with the public finance agenda so that the pension system designed (i) promotes pension saving and (ii) provides the poor with decent old-age pensions. In addition to these two objectives, hard enough to achieve as it is, any new design is now expected to contribute to others as well: (iii) keeping the public finances solvent; (iv) generating financial saving to develop the capital market; and (v) contributing to competitiveness.
To rank and harmonize these objectives, there needs to be a very wide-ranging political agreement that allows five major strategies to be reconciled. First, at the macroeconomic and institutional level, a strategy to protect the growth and investment capacity of the economy in a context of nominal and real stability. This means that the social agreement needs to recognize the importance of a macroeconomic and institutional pillar whereby countercyclical policies are implemented through structural surplus rules and/or stabilization funds, financial and pension fund markets are strictly regulated and monitored, and clear rules 
are laid down for monetary, currency and international reserves management, in order to give credibility to the real exchange rate and interest rate.

Second, a strategy for permanently reconciling (which also means adapting) the pension system to the structures and dynamics of the population, the labour market and the public finances. There is no one pension system that is right for different countries, or for any given country over time. The model needs to be continually adapting to changes in demographic structures, families, the labour market and the public finances, and must always include criteria of universality and solidarity so that, with minimum but socially accepted benefits, its financing and form of administration do not leave people underinsured or uninsured.

Third, a strategy for strengthening the contribution base over the long term, since as well as improving the economic and financial underpinnings of growth (macroeconomic pillar), there is also a need to improve the productive capacity of members. This strategy recognizes two further pillars: one of human capital formation through education and workforce training, and one of productive development and employment, designed to take advantage of the country's niches and potential and to stimulate the needful research and development.

Fourth, a strategy that includes both solidarity saving mechanisms to finance benefits (with special emphasis on rewarding saving efforts through definedcontribution systems) and actuarially determined guarantee funds for the provision of minimum benefits. The challenge is to regulate the way benefits are financed so that the principles of equivalence and solidarity are reconciled. The essential thing in each social contract is that benefits should not exceed duly capitalized contributions. These principles clash when equivalence is practised in individual contracts without any provision for cross-subsidies in the interests of solidarity (figure 26).

What ECLAC proposes is to give social content to the fiscal covenant by creating a social agreement that orients it, and to do this by means of five pillars, the fifth being participatory democracy (table 5). This last pillar promotes civic participation in the fundamental decisions that a society needs to take, particularly as
FIGURE 26

Illustration of a contributory pillar combined with a solidarity pillar

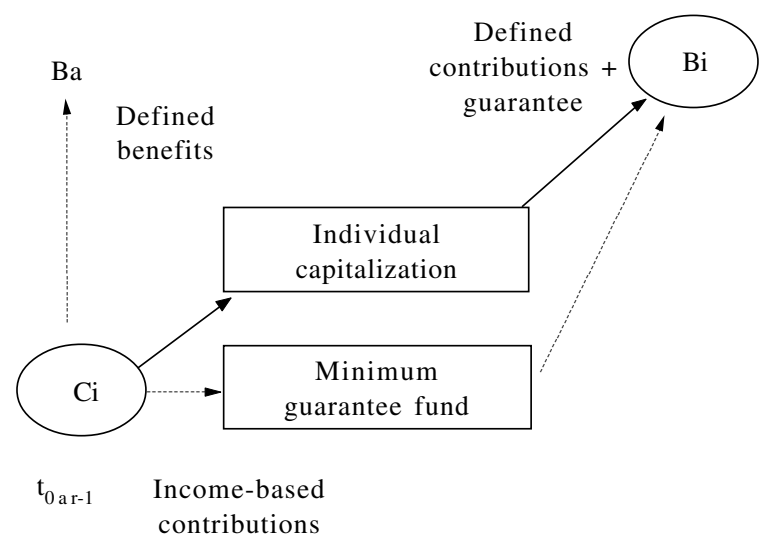

Source: Prepared by the author.

regards improvements to the immediate and long-term coverage and benefits of pension systems. These systems, therefore, need to be flexible enough to adapt to the different stages in a society's development, and in each case decisions will be required as to how much of the system's funds can be put into financial instruments, given the financial constraints of the society concerned and the way these manifest themselves in the heterogeneous world constituted by different types of families, production units and employment opportunities.

For coverage to be extended, considering the gaps in the welfare State, financing sources and administration mechanisms need to be highly specific. Unquestionably, however, the trio of market, family and State cannot provide universal cover until there is a social agreement dealing with (i) explicit minimum benefit guarantees, (ii) solidarity financing sources and (iii) the prerequisites for benefit entitlement. The speed at which the Latin American population is ageing, the effect that the constant adaptation of the production apparatus to new conditions of competitiveness has been having on employment, and the various ways in which society has been reacting to survive under these conditions, have made social protection in the area of pensions a core challenge, the responses to which must constantly be adapted to the characteristics of each particular situation. 
Components required for a social agreement compatible with a fiscal covenant

\begin{tabular}{|c|c|c|c|c|}
\hline \multicolumn{4}{|c|}{ Agreement compatible with a fiscal covenant } & \multirow{2}{*}{$\begin{array}{l}\text { Democracy } \\
\text { Improved } \\
\text { social cohesion }\end{array}$} \\
\hline $\begin{array}{l}\text { Fiscal } \\
\text { responsibilities }\end{array}$ & $\begin{array}{l}\text { Important role } \\
\text { for education }\end{array}$ & $\begin{array}{l}\text { More and } \\
\text { better jobs }\end{array}$ & $\begin{array}{l}\text { Universal, redistributive } \\
\text { and efficient social } \\
\text { security }\end{array}$ & \\
\hline $\begin{array}{l}\text { Minimum guarantees } \\
\text { Improved productivity } \\
\text { in the public provision } \\
\text { of public or socially } \\
\text { valuable goods }\end{array}$ & $\begin{array}{l}\text { Universal secondary } \\
\text { education } \\
\text { Narrowing of the } \\
\text { gaps between elite } \\
\text { and public education } \\
\text { Preschool education } \\
\text { for the poor } \\
\text { Learning to learn } \\
\text { School insurance }\end{array}$ & $\begin{array}{l}\text { Measures to deal } \\
\text { with productive } \\
\text { heterogeneity } \\
\text { Consideration } \\
\text { of productive } \\
\text { heterogeneity } \\
\text { Investing } \\
\text { for jobs } \\
\text { Human resources } \\
\text { approach } \\
\text { Reduction of } \\
\text { discrimination } \\
\text { Improved labour } \\
\text { relations, considering } \\
\text { the needs of innovation } \\
\text { and the economic cycle } \\
\text { Reskilling } \\
\text { Unemployment } \\
\text { insurance }\end{array}$ & $\begin{array}{l}\text { Reform of } \\
\text { public-private } \\
\text { combinations } \\
\text { Incorporation of } \\
\text { solidarity into } \\
\text { financing to } \\
\text { improve access } \\
\text { without sacrificing } \\
\text { saving and insurance } \\
\text { Better protection } \\
\text { against contingent } \\
\text { risks } \\
\text { Financing of } \\
\text { housing for the poor }\end{array}$ & $\begin{array}{l}\text { Promotion of } \\
\text { citizen involvement } \\
\text { in aspects of } \\
\text { collective interest } \\
\text { Enhancement of } \\
\text { governance by } \\
\text { revising the incentives } \\
\text { for investing in basic } \\
\text { social services that } \\
\text { have been privatized } \\
\text { and improving their } \\
\text { regulatory framework }\end{array}$ \\
\hline
\end{tabular}

Source: Prepared by the author, on the basis of ECLAC (2004b and 2000).

\section{Bibliography}

AIOS (International Association of Pension Funds' Supervisory Organisations) (2005): Boletín estadístico, No. 13, Buenos Aires, June.

Arenas de Mesa, A. (2000): Proyecciones del déficit previsional chileno: gasto público en pensiones asistenciales 1999. 2010, Seminarios y conferencias series, No. 3, LC/L.1456$\mathrm{P}$, Santiago, Chile, Economic Commission for Latin America and the Caribbean (ECLAC).

Arenas de Mesa, A. and J. Guzmán Cox (2003): Política fiscal y protección social: sus vínculos en la experiencia chilena, Financiamiento del desarrollo series, No. 136, LC/L.1930-P, Santiago, Chile, Economic Commission for Latin America and the Caribbean (ECLAC), July.

Arenas de Mesa, A., J. Behrman and D. Bravo (2004): Characteristics and determinants of the density of contributions in a private social security system, document presented at the Encuentro Anual 2004 de la Sociedad de Economistas de Chile, Santiago, Chile, August.

Arenas de Mesa, A., M.C. Llanes and F. Miranda Bravo (2005): Protección social efectiva, calidad de la cobertura y efectos distributivos del sistema de pensiones en Chile, Santiago, Chile, Economic Commission for Latin America and the Caribbean (ECLAC), unpublished.
Arrau, P. (1994): Fondos de pensiones y desarrollo del mercado de capitales en Chile: 1980-1993, Financiamiento del desarrollo series, No. 19, LC/L.839, Santiago, Chile, Economic Commission for Latin America and the Caribbean (ECLAC).

(1996): Nota sobre el aumento del ahorro nacional en Chile, Financiamiento del desarrollo series, No. 39, LC/ L.984, Santiago, Chile, Economic Commission for Latin America and the Caribbean (ECLAC).

Arriagada, I. (comp.) (2005): Políticas hacia las familias, protección e inclusión sociales, Seminarios y conferencias series, No. 46, LC/L.2373-P, Santiago, Chile, Economic Commission for Latin America and the Caribbean (ECLAC), October. United Nations publication, Sales No. S.05.II.G.118. Bernstein, S. and J. Ruiz (2005): Sensibilidad de la demanda con consumidores desinformados: el caso de las AFP en Chile, Documentos de trabajo series, No. 4, Santiago, Chile, Superintendencia de Administradoras de Fondos de Pensiones, April.

Bernstein, S., G. Larraín and F. Pino (2005): Cobertura, densidad y pensiones en Chile: proyecciones a 30 años plazo, Santiago, Chile, División de Estudios, Superintendencia de Administradoras de Fondos de Pensiones, unpublished. 
Bertranou, F. and A. Sánchez (2003): Características y determinantes de la densidad de aportes a la seguridad social en la Argentina 1994-2001, Historias laborales en la seguridad social, Buenos Aires, ILo Office in Argentina/ Ministry of Labour, Employment and Social Security, October.

Bravo, J. and A. Uthoff (1999): Transitional Fiscal Costs and Demographic Factors in Shifting from Unfunded to Funded Pensions in Latin America, Financiamiento del desarrollo series, No. 88, LC/L.1264-P, Santiago, Chile, Economic Commission for Latin America and the Caribbean (ECLAC). United Nations publication, Sales No. E.99.II.G.38.

Bucheli, M., A. Forteza and N. Ferreira-Coimbra (2005): El acceso a la jubilación o pensión en Uruguay: ¿cuántos y quiénes lo lograrían?, Estudios y perspectivas series, No. 4 LC/L.2487-P, Montevideo, ECLAC office in Montevideo. United Nations publication, Sales No. S.06.II.20.

Corbo, V. and K. Schmidt-Hebbel (2003): Efectos macroeconómicos de la reforma de pensiones en Chile, Resultados y desafíos de las reformas de pensiones, Santiago, Chile, Corporación de Investigación, Estudio y Desarrollo de la Seguridad Social (CIEDESS)/International Federation of Pension Fund Administrators (FIAP).

ECLAC (Economic Commission for Latin America and the Caribbean) (1991): Sistemas de pensiones de América Latina. Diagnóstico y alternativas de reforma. Estudios de caso de América Latina y el Caribe. Conclusiones y recomendaciones, Financiamiento del desarrollo series, No. 9, LC/L.656, Santiago, Chile.

(1996): Strengthening Development. The Interplay of Macro- and Microeconomics, Libros de la CEPAL series, No. 42, LC/G.1898/Rev.1-P, Santiago, Chile. United Nations publication, Sales No. E. 96.II.G.12. (1998): The Fiscal Covenant: Strengths, Weaknesses, Challenges, LC/G.1997/Rev.1-P, Santiago, Chile. United Nations publication, Sales No. E.98.II.G.5.

(2000): Equity, Development and Citizenship, LC/ G.2071/Rev.1-P, Santiago, Chile, August. United Nations publication, Sales No. E.00.II.G.81. (2002): Globalización y desarrollo (LC/G.2157(SES29./ 3)), Santiago, Chile, April. (2004a): Social Panorama of Latin America, 2004, LC/L.2259-P, Santiago, Chile. United Nations publication, Sales No. E.04.II.G.148.

(2004b): Productive Development in Open Economies, LC/G.2234, Santiago, Chile, June.

(2005a): The Millennium Development Goals: A Latin American and Caribbean Perspective, LC/G.2331-P, Santiago, Chile. United Nations publication, Sales No. E.05.II.G.107. (2005b): Economic Survey of Latin America and the Caribbean, 2004-2005, LC/G.2279-P, Santiago, Chile. United Nations publication, Sales No. E.05.II.G.2.

(2005c): Social Panorama of Latin America, 2005, LC/G.2288-P, Santiago, Chile. United Nations publication, Sales No. E.05.II.G.161.

Fajnzylber, E. (2005): Sistemas de capitalización, densidad de cotizaciones, y cobertura contributiva, working paper, Santiago, Chile, Economic Commission for Latin America and the Caribbean (ECLAC), unpublished.

Gill, I., T. Packard and J. Yermo (2004): Keeping the Promise of Old Age Income Security in Latin America, Washington, D.C., World Bank.

Held, G. (1994): Liberalization or financial development?, CEPAL Review, No. 54, LC/G.1845-P, Santiago, Chile, Economic Commission for Latin America and the Caribbean (ECLAC), December.

Holzmann, R. (1997): On economic benefits and fiscal requirements of moving from unfunded to funded pensions, Financiamiento del desarrollo series, No. 48, LC/L.1013, Santiago, Chile, Economic Commission for Latin America and the Caribbean (ECLAC).

Holzmann, R., R. Hinz and others (2005): Old Age Income Support in the Twenty-first Century: an International Perspective on Pension Systems and Reform, Washington, D.C., World Bank, electronic version.

ILO (International Labour Organization) (2005): Panorama laboral 2005, Lima, Regional Office for Latin America and the Caribbean.

Jiménez, L. and J. Cuadros (2003): Evaluación de las reformas a los sistemas de pensiones: cuatro aspectos críticos y sugerencias de políticas, Financiamiento del desarrollo series, No. 131, LC/L.1913-P, Santiago, Chile, Economic Commission for Latin America and the Caribbean (ECLAC), June. United Nations publication, Sales No. S.03.II.G.71.

Lagomarsino, G. and B. Lanzilotta (2004): Densidad de aportes a la seguridad social en Uruguay. Análisis de su evolución y determinantes a partir de los datos registrales de historia laboral (1997-2003), document prepared for the Equipo de Representación de los Trabajadores en el Banco de Previsión Social (BPS), Montevideo, December

Larraín, C. (1996): Operación de conglomerados financieros en Chile: una propuesta, Financiamiento del desarrollo series, No. 37, LC/L.949, Santiago, Chile, Economic Commission for Latin America and the Caribbean (ECLAC).

Machinea, J.L. and A. Uthoff (eds.) (2005): Integración económica y cohesión social: lecciones aprendidas y perspectivas, LC/W.29, Santiago, Chile, United Nations, October.

Marco, F. (ed.) (2004): Los sistemas de pensiones en América Latina: un análisis de género, Cuadernos de la CEPAL series, No. 90, LC/G.2262-P, Santiago, Chile, October. United Nations publication, Sales No. S.04.II.G.129.

Morley, S., R. Machado and S. Pettinato (1999): Indexes of Structural Reform in Latin America, Reformas económicas series, No. 12, LC/L.1166-P, Santiago, Chile, Economic Commission for Latin America and the Caribbean (ECLAC).

Mesa-Lago, C. (2000): Desarrollo social, reforma del Estado y de la seguridad social, al umbral del siglo XXI, Políticas sociales series, No. 36, LC/L.1249-P, Santiago, Chile, Economic Commission for Latin America and the Caribbean (ECLAC). United Nations publication, Sales No. S.00.II.G.5.

(2004): Las reformas de pensiones en América Latina y su impacto en los principios de la seguridad social, Financiamiento del desarrollo series, No. 144, LC/L.2090P, Santiago, Chile, Economic Commission for Latin America and the Caribbean (ECLAC). United Nations publication, Sales No. S.04.II.G.29.

Pinheiro, C. and S. Paiva (2000): Reforma previsional en Brasil: la nueva regla para el cálculo de los beneficios, Financiamiento del desarrollo series, No. 97, LC/L.1386P, Santiago, Chile, Economic Commission for Latin America and the Caribbean (ECLAC). United Nations publication, Sales No. S.00.II.G.62.

Reyes, G. (2004): Razones para no cotizar, Santiago, Chile, División de Estudios, Superintendencia de Administradora de Fondos de Pensiones, unpublished.

Smeeding, T. and K. Ross (2001): Social protection for the poor in the developed world: the evidence from LIS, in N. Lustig, Shielding the Poor. Social Protection in the Developing World, Washington, D.C., Inter-American Development Bank.

St. John, S. and L. Willmore (2001): Two legs are better than three: New Zealand as a model for old age pensions, World Development, vol. 29, No. 8, Amsterdam, Elsevier, August.

Titelman, D. and A. Uthoff (2005): The role of insurance in social protection in Latin America, International Social 
Security Review, vol. 58, No. 2-3, Oxford, United Kingdom, Blackwell Publishing.

Uthoff, A. (1995): Pension system reform in Latin America, CEPAL Review, No. 56, LC/G.1874-P, Santiago, Chile, Economic Commission for Latin America and the Caribbean (ECLAC), August.

Uthoff, A. and N. Ruedi (2005): Protección social en las familias: un análisis a partir de las encuestas de hogares, in I. Arriagada (ed.), Políticas hacia las familias, protección e inclusión sociales, Seminarios y conferencias series, No. 46, LC/L.2373-P, Santiago, Chile, Economic Commission for Latin America and the Caribbean (ECLAC), October. United Nations publication, Sales No. S.05.II.G.118.

Uthoff, A., C. Vera and N. Ruedi (2006): Relación de dependencia del trabajo formal y brechas de protección social en América Latina y el Caribe, Financiamiento del desarrollo series, No. 169, LC/L.2497-P, Santiago, Chile, Economic Commission for Latin America and the Caribbean (ECLAC), February.

World Bank (1994): Averting the Old-Age Crisis: Policies to protect the Old and Promote Growth, Washington, D.C. (2004): World Development Indicators, Washington, D.C., April. 